\title{
As espécies de Terpsichore A.R. Sm. e Zygophlebia L.E. Bishop (Grammitidaceae) do Brasil ${ }^{1}$
}

\author{
Paulo Henrique Labiak ${ }^{2,4}$ e Jefferson Prado ${ }^{3}$
}

Recebido em 15/06/2004. Aceito em 17/05/2005

\begin{abstract}
RESUMO - (As espécies de Terpsichore A.R. Sm. e Zygophlebia L.E. Bishop (Grammitidaceae) do Brasil). O presente trabalho apresenta um tratamento taxonômico para as espécies de Terpsichore e Zygophlebia que ocorrem no Brasil. Das 12 espécies de Terpsichore, nove ocorrem na Floresta Atlântica do sudeste e sul do Brasil, quatro na Cadeia do Espinhaço, em Minas Gerais e quatro nas cadeias de montanhas próximas às fronteiras entre o Brasil, Venezuela e Guianas. O gênero Zygophlebia, representado por uma espécie (Zygophlebia longipilosa (C.Chr.) L.E. Bishop, ocorre apenas na Floresta Atlântica brasileira. São apresentadas considerações acerca da classificação, uma análise crítica sobre cada táxon e seus sinônimos, descrições e distribuição geográfica das espécies, bem como chaves para identificação, comentários sobre as espécies mais semelhantes e ilustrações.
\end{abstract}

Palavras-chave: Pteridófitas, Grammitidaceae, Terpsichore, Zygophlebia, Brasil

\begin{abstract}
The species of Terpsichore A.R. Sm. and Zygophlebia L.E. Bishop (Grammitidaceae) from Brazil). This works presents the taxonomic treatment for the species of Terpsichore and Zygophlebia that occurs in Brazil. Terpsichore is represented by 12 species, mostly occuring in the southeastern and southern Brazilian Atlantic Rain Forest, and a few (four) that are endemic to the mountains by the boundary between Brazil, Venezuela and Guayana. The genus Zygophlebia, with only one species (Zygophlebia longipilosa (C.Chr.) L.E. Bishop) is endemic to the Atlantic Rain Forest of southeastern and southern Brazil. In this paper are included a critical analysis of each species and their synonymy, as well as geographical distribution, identification keys, comments about related species, and illustrations.
\end{abstract}

Key words: Ferns, Grammitidaceae, Terpsichore, Zygophlebia, Brazil

\section{Introdução}

O presente trabalho é continuação de uma série de estudos sobre as espécies de Grammitidaceae do Brasil. Dentre os trabalhos recentes já publicados sobre a família no País, destacam-se os de Labiak (2000; 2003), com a descrição de novas espécies e novas combinações para espécies brasileiras; de Labiak \& Prado (2003), que apresentaram considerações sobre a morfologia geral da família, dados sobre distribuição geográfica, chave para os gêneros do Brasil e tratamento taxonômico para os gêneros Ceradenia L.E. Bishop, Cochlidium Kaulf. e Grammitis Sw.; e de Labiak \& Prado (2005a; 2005b).

As relações da família Grammitidaceae com Polypodiaceae s.s. têm sido ainda amplamente discutidas, principalmente porque em hábito, divisão da lâmina e ausência de indúsio, algumas espécies de Grammitidaceae lembram espécies pequenas de
Polypodium. Discussão mais detalhada sobre estas relações pode ser encontrada em Labiak \& Prado (2003).

Este trabalho apresenta uma revisão taxonômica para as espécies dos gêneros Terpsichore A.R. Sm. e Zygophlebia L.E. Bishop que ocorrem no Brasil, com chaves de identificação, sinonímias, descrições, lista de materiais examinados, ilustrações e comentários sobre as espécies.

\section{Material e métodos}

O presente estudo foi baseado na análise dos espécimes depositados nos herbários $\mathrm{BHCB}, \mathrm{BM}, \mathrm{BR}$, FLOR, GH, GUA, HB, HBR, HRCB, INPA, IPA, K, MBM, NY, OUPR, PACA, PEUFR, R, RB, SJRP, SP, SPF, UC, UEC, VIC, HUFU, CESJ, UFP, UPCB e US, bem como no trabalho de campo. Os espécimes coletados durante as excursões encontram-se depositados nos herbários SP, SPF e MBM.

\footnotetext{
1 Parte da Tese de Doutorado do primeiro Autor

2 Universidade Federal do Paraná, Departamento de Botânica, C. Postal 19031, CEP 81531-980, Curitiba, PR, Brasil

3 Instituto de Botânica, C. Postal 4005, CEP 01061-970, São Paulo, SP, Brasil

4 Autor para correspondência: plabiak@ufpr.br
} 
Foram citados os materiais brasileiros relevantes para cada táxon e uma lista dos materiais adicionais examinados, que referendam a ocorrência extra-Brasil para algumas espécies.

A classificação adotada para a família segue os conceitos apresentados principalmente nos trabalhos de Bishop (1974; 1977; 1978; 1988; 1989), Bishop \& Smith (1992; 1995), Smith \& Moran (1995) e Smith $(1992 ; 1993 ; 1995)$.

Os termos utilizados para a caracterização morfológica dos táxons seguem Font Quer (1989), Rizzini \& Rizzini (1983) e Stearn (1995), com algumas modificações principalmente no que se refere aos termos hidatódios e setas, que seguiram os conceitos propostos por de la Sota et al. (2000). Para visualização do padrão de venação foi utilizado o método de diafanização de Foster (1949) e, para as características do indumento e dos esporos, foram realizadas fotografias em microscópio eletrônico de varredura.

Os nomes de autores foram abreviados segundo Pichi-Sermolli (1996).

A distribuição geográfica geral é apresentada com base em espécimes analisados e dados de bibliografia. A distribuição dos táxons no Brasil foi baseada apenas nos espécimes estudados. No presente estudo, considerou-se região Mesoamericana como apresentado por Davidse et al. (1995), a qual inclui, além dos países continentais da América Central (desde a Guatemala ao Panamá), a região sul do México.

$\mathrm{O}$ tratamento taxonômico conjunto dos gêneros Terpsichore e Zygophlebia, como aqui organizado, reflete apenas uma maneira conveniente de apresentação dos resultados obtidos, por ocasião dos estudos das espécies de Grammitidaceae no Brasil (Labiak 2000; 2003; Labiak \& Prado 2003), não pretendendo sugerir qualquer relação filogenética entre esses táxons.

\section{Resultados e discussão}

Terpsichore A.R. Sm., Novon 3: 479. 1993. Tipo: Polypodium asplenifolium L. (=Terpsichore asplenifolia (L.) A.R. Sm.).

Plantas epífitas, rupícolas ou raramente terrestres, com crescimento determinado ou indeterminado. Caule radialmente simétrico, curto-reptante ou ascendente, escamas não clatradas, basifixas, monocromáticas, cílios ausentes ou presentes, se presentes esbranquiçados ou concolores com a escama, filopódios ausentes. Frondes monomorfas, cespitosas; pecíolo ausente ou tão comprido quanto a lâmina, setuloso (especialmente na base) e geralmente puberulento, setas 0,5-3 $\mathrm{mm}$ compr., numerosas, patentes, geralmente castanhas, tricomas de 0,1-0,2 mm compr., ramificados ou simples, castanho-claros, às vezes glandulares; lâmina pinatissecta a 1-pinada, raramente 1-pinado-pinatífida, geralmente setulosa (pelo menos ao longo da raque); nervuras simples, geralmente pinadas; hidatódios presentes, escuros ou às vezes com pontos esbranquiçados. Soros arredondados, superficiais, sem paráfises; esporângios glabros ou ciliados.

O gênero Terpsichore é definido basicamente pela presença de hidatódios conspícuos na superfície adaxial da lâmina, pecíolo, raque e a lâmina geralmente recobertos por setas castanhas e/ou tricomas ramificados ou simples (Fig. 1-5), e pelas escamas do caule não clatradas e geralmente com cílios na margem (algumas vezes ausentes ou apenas um cílio apical) (Fig. 9-12).

Em determinados grupos de espécies as frondes apresentam crescimento indeterminado e geralmente são pendentes e membranáceas. As espécies com crescimento determinado geralmente são eretas ou apenas levemente arqueadas, apresentando textura cartácea a coriácea.

Smith (1993) considerou cinco principais grupos de espécies no gênero, a saber:

1. Grupo de Terpsichore asplenifolia (aproximadamente $12 \mathrm{spp}$.): frondes pendentes, com crescimento determinado; caule dorsiventral ou radial, com escamas estramíneas a castanhas, com cílios na margem e algumas vezes também na superfície da escama; o pecíolo é distinto e a lâmina não ou abruptamente reduzida para a base, com setas castanhas simples; os esporângios ciliados, e hidatódios não produzindo secreções calcáreas na superfície adaxial da lâmina. Fungos claviformes ausentes na superfície laminar.

2. Grupo de Terpsichore taxifolia (aproximadamente $13 \mathrm{spp}$.): frondes eretas a arqueadas, com crescimento determinado; caule geralmente dorsiventral, com escamas castanhas, ciliadas no ápice e algumas vezes também na margem; pecíolo distinto e lâmina levemente reduzida na base, com setas castanhas simples; esporângios glabros e hidatódios frequentemente não produzindo secreções calcáreas na superfície da lâmina. Fungos claviformes presentes na superfície laminar.

3. Grupo de Terpsichore lanigera (aproximadamente 16 spp.): frondes pendentes, com crescimento indeterminado; caule geralmente radialmente simétrico, 
com escamas castanhas a estramíneas, marginalmente ciliadas (Fig. 12) (escamas ausentes em T. alfarii (Donn. Sm.) A.R. Sm.); pecíolo geralmente menor que $1 \mathrm{~cm}$ compr. e lâmina longamente reduzida para a base da fronde, com setas simples ou geralmente pareadas; esporângios ciliados (exceto em $T$. delicatula (M. Martens \& Galeotti) A.R. Sm., T. jamesonioides (Fée) A.R. Sm. e T. spathulata A.R. Sm.), e hidatódios produzindo secreções calcáreas em algumas poucas espécies. Fungos claviformes ausentes.

4. Grupo de Terpsichore subtilis (2 spp.): frondes arqueadas ou algumas vezes pendentes, com crescimento indeterminado; caule dorsiventral a radial, revestido por escamas castanho-escuras, com apenas um cílio apical ou algumas vezes marginalmente ciliadas; pecíolo menor que $1 \mathrm{~cm}$ compr. e lâmina não ou abruptamente reduzida para a base da fronde, com setas castanhas simples; esporângios glabros e hidatódios não produzindo secreções calcáreas na superfície da lâmina. Fungos claviformes ausentes.

5. Grupo de Terpsichore achilleifolia (3 spp.): frondes eretas ou arqueadas, com crescimento determinado; caule geralmente dorsiventral, com escamas estramíneas a castanho-claras, glabras a ligeiramente glandulares (Fig. 10); pecíolo distinto e lâmina não ou abruptamente reduzida para a base da fronde, com setas castanhas simples; esporângios glabros e hidatódios não produzindo secreções calcáreas na superfície da lâmina. Fungos claviformes ausentes.

Embora as relações entre esses grupos não sejam ainda bem estabelecidas, as características do pecíolo, as frondes pendentes, a simetria radial do caule, as setas ramificadas e os esporângios ciliados são admitidos por Smith (1993) como caracteres derivados dentro do gênero.

As escamas estramíneas do grupo de Terpsichore achilleifolia (Kaulf.) A.R. Sm. são incomuns dentro do gênero e poderiam indicar uma relação com o gênero Micropolypodium ou com algumas espécies de Ctenopteris do Velho Mundo (Smith 1993). No entanto não existem dados suficientes para qualquer conclusão acerca das reais relações entre estes gêneros.

A forma da fronde, no grupo de Terpsichore asplenifolia (L.) A.R. Sm., parece ser uma condição ancestral em Grammitidaceae, dando origem ao grupo de T. taxifolia (L.) A.R. Sm., também tido como um grupo ancestral dentro do gênero. Ambos os grupos apresentam ainda caule de simetria dorsiventral, o que Bishop (1989) considerou também uma condição ancestral dentro da família.
Quanto ao caráter da divisão da fronde, as formas 1-pinado-pinatissectas de algumas espécies de Terpsichore são incomuns no gênero, mas podem ser encontradas em diversas espécies de Lellingeria. Segundo Smith (1993), esse caracter pode ter surgido várias vezes entre as Grammitidaceae neotropicais e em algumas espécies do Velho Mundo (gênero Ctenopteris), o que não sugere, necessariamente, qualquer relação de parentesco entre os gêneros.

Característica bastante peculiar de algumas espécies em Terpsichore é a presença de corpos de frutificação de fungos (provavelmente Acrospermum maxonii Farlow) principalmente sobre a raque, costa e nervuras (Mickel 1973) (Fig. 6). Segundo Smith (1993), a presença desses fungos em dois dos grupos de Terpsichore poderia indicar uma origem monofilética das espécies (aproximadamente 15) que compõem esses grupos.

Os esporângios geralmente formam soros arredondados, sendo glabros ou apresentando cílios no ânulo (Fig. 7-8). Os esporos são geralmente globosos ou algumas vezes tetraédrico-globosos, triletes, com as aperturas obscuras e a superfície levemente papilada (Fig. 13-16). A importância taxonômica dos esporos dentro do gênero é ainda incerta, pois uma quantidade insuficiente de dados está atualmente disponível na literatura (Smith 1993).

Wagner (1985) registrou a presença de esporos elipsóides monoletes em Grammitis lanigera (Desv.) C.V. Morton e G. senilis (Fée) C.V. Morton (atualmente tratadas em Terpsichore). Da mesma forma, Smith (1993) encontrou esporos elipsóides, monoletes, bilaterais em Terpsichore longa (C. Chr.) A.R. Sm., T. mollissima (Fée) A.R. Sm., T. senilis (Fée) A.R. Sm. e T. xanthotrichia (Klotzsch) A.R. Sm. Segundo Smith (1993), algumas espécies podem manifestar essa característica de forma inconstante, como T. cultrata (Bory ex Willd.) A.R. Sm., T. laninera (Desv.) A.R. Sm. e T. laxa (C. Presl) A.R. Sm. Porém, de uma forma geral, as espécies de Terpsichore apresentam caracteristicamente esporos globosos, triletes, conforme registrado para as espécies brasileiras analisadas.

A presença de esporos monoletes, em algumas espécies, constitui um estado de caracter ainda não suficientemente conhecido para o grupo. No entanto, Smith (1993) o considerou como um estado derivado em Grammitidaceae, o que não implicaria em nenhuma afinidade com Pecluma M.G. Price ou outros grupos de Polypodiaceae que apresentam esporos bilaterais monoletes. 
870 Labiak \& Prado: As espécies de Terpsichore A.R. Sm. e Zygophlebia L.E. Bishop (Grammitidaceae) do Brasil
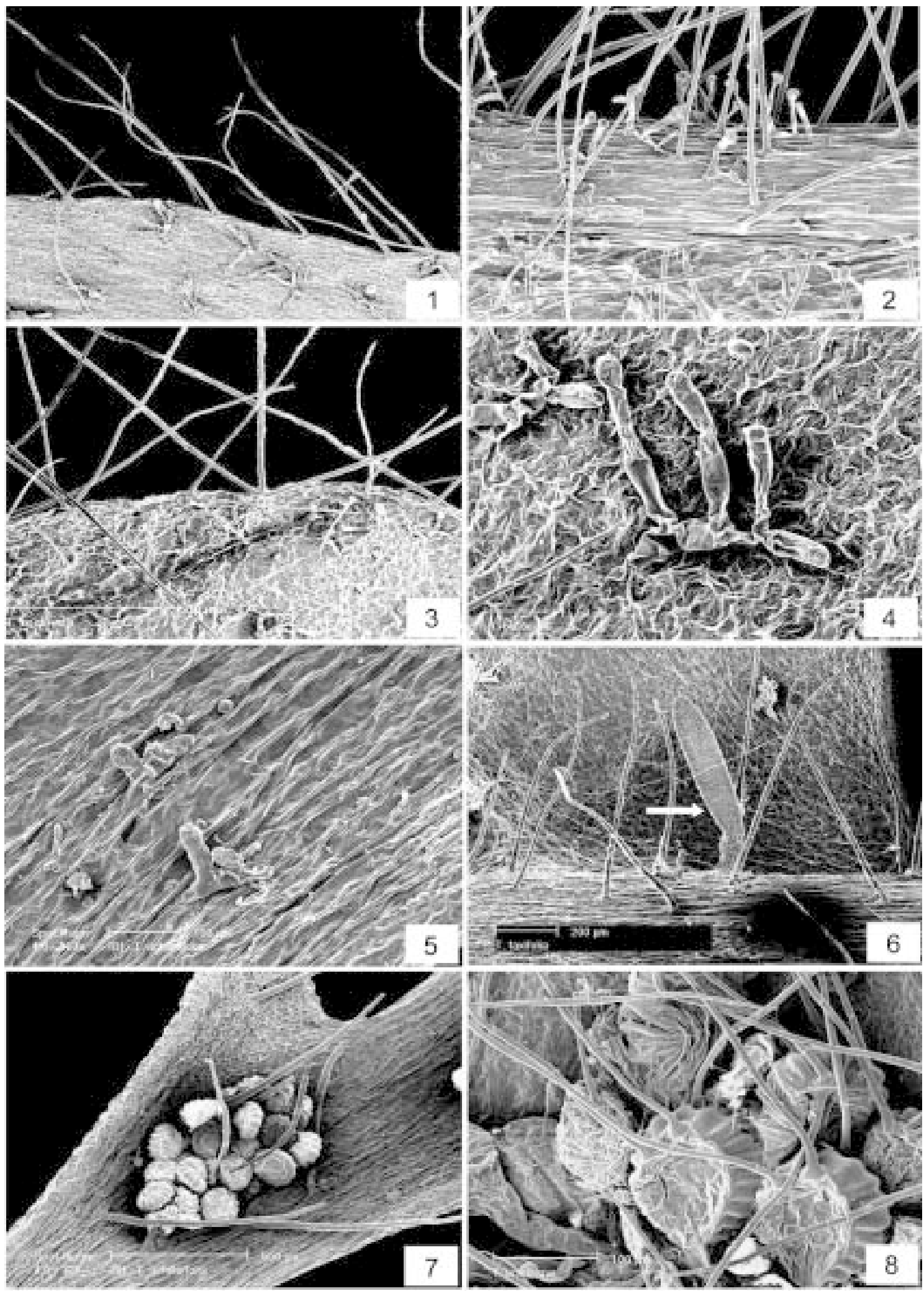

Figuras 1-8. 1. Terpsichore bradeana Labiak (Prance 10075). Setas e tricomas ramificados sobre a lâmina. 2-3. T. reclinata (Brack.) Labiak (Labiak 964). 2. Raque com setas e tricomas ramificados na face abaxial. 3. Setas ramificadas na margem do segmento. 4. T. bradeana (Prance 10075). Tricoma ramificado sobre a lâmina. 5. T. achilleifolia (Kaulf.) A.R. Sm (Labiak 491). Tricoma simples sobre a lâmina. 6. T. taxifolia (L.) A.R. Sm. (Labiak 963). Setas e fungos claviformes sobre a face abaxial da raque. 7. T. achilleifolia (Labiak 491). Esporângios glabros. 8. T. bradeana (Prance 10075). Esporângios ciliados. 

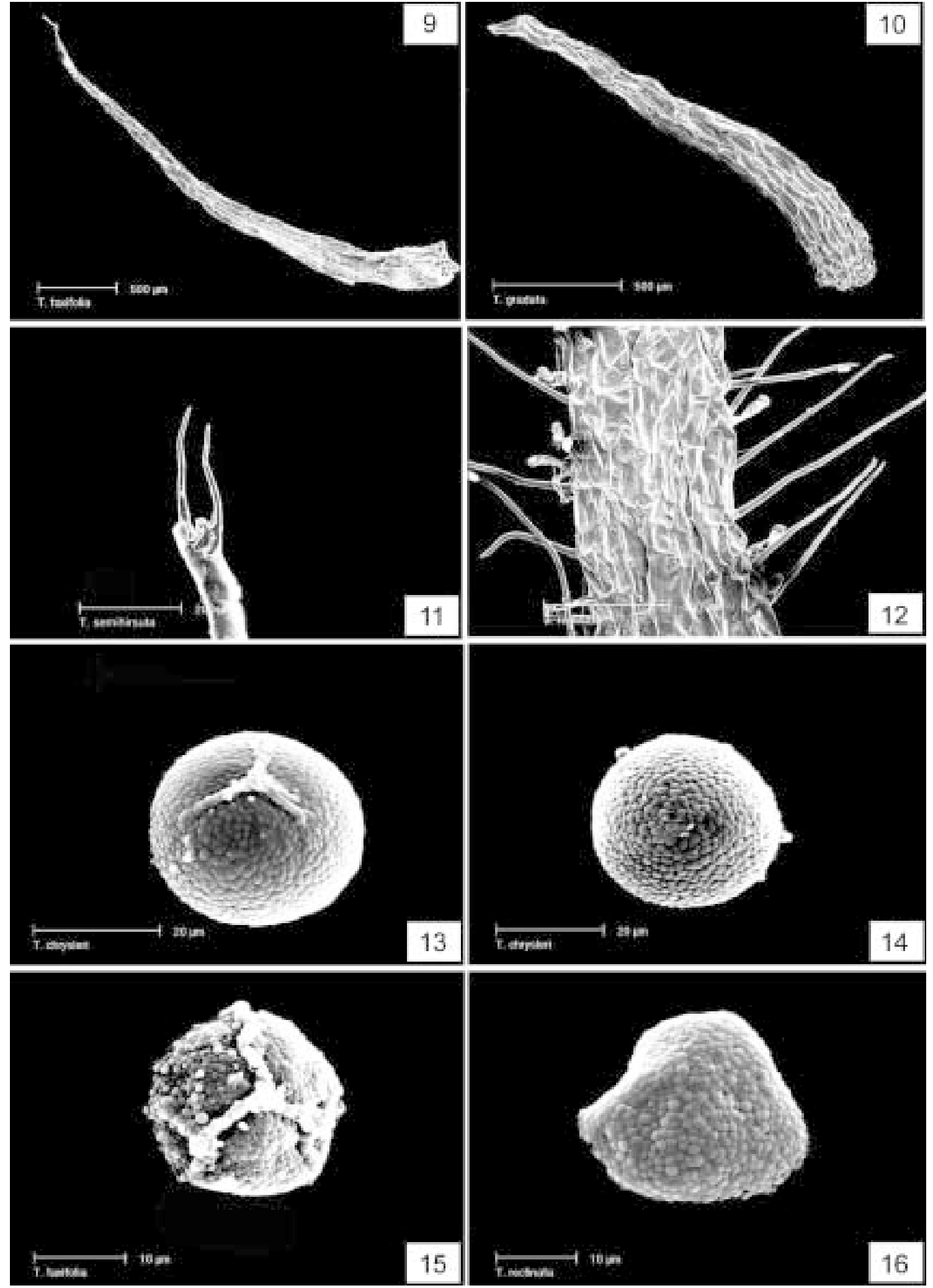

Figuras 9-16. 9. Terpsichore taxifolia (L.) A.R. Sm. (Labiak 963). Escama do caule com cílio apical. 10. T. gradata (Baker) A.R. Sm. (Labiak 486). Escama do caule. 11. T. semihirsuta (Klotzsch) A.R. Sm. (Brade 9644). Detalhe do ápice da escama do caule com cílios apicais. 12. T. reclinata (Brack.) Labiak (Labiak 964). Detalhe da escama do caule com cílios nas margens. 13-14. T. chrysleri (Copel) A.R. Sm. (Labiak 982). 13. Esporo em vista proximal. 14. Esporo em vista distal. 15. T. taxifolia (Labiak 963). Esporo em vista proximal. 16. T. reclinata (Labiak 964). Esporo em vista distal. 
O número cromossômico do gênero é conhecido apenas para Terpsichore asplenifolia (L.) A.R. Sm. $(\mathrm{n}=37)$, T. semihirsuta (Klotzsch) A.R. Sm. $(\mathrm{n}=74)$ e T. lanigera (Desv.) A.R. Sm. $(\mathrm{n}=37)$ (Walker 1966, 1985). Esses dados sugerem que o número cromossômico base para o gênero é $\mathrm{x}=37$, sendo esse igual a média cromossômica encontrada em outros gêneros de Grammitidaceae.

Algumas espécies de Terpsichore, principalmente do grupo de Terpsichore taxifolia, são bastante semelhantes às espécies do gênero Pecluma. Esse, porém, pode ser distinguido por apresentar um filopódio curto, esporos monoletes amarelos, escamas comosas e a ausência de setas castanhas no pecíolo e lâmina foliar.

Alguns grupos de espécies mais relacionados a Terpsichore são atualmente tratadas em Ctenopteris, um gênero bastante diverso e provavelmente polifilético, tipificado por $C$. venulosa (Blume) Kunze, do Velho Mundo. O gênero Cryptosorus Fée (por vezes tratado como sinônimo de Ctenopteris) possui também espécies semelhantes a Terpsichore. No entanto, os tipos desses gêneros, e de muitas outras espécies do Velho Mundo, diferem dos das espécies de Terpsichore por não possuírem hidatódios, apresentarem escamas subclatradas e os soros localizados em criptas. Entretanto, em algumas espécies do Velho Mundo esses caracteres se manifestam como nas espécies de Terpsichore e, sugestivamente, a relação entre essas espécies do Velho Mundo e as Neotropicais necessita ainda ser mais bem compreendida (Smith 1993).

Os representantes do gênero Terpsichore geralmente habitam as regiões de elevada altitude do Neotrópico, onde existem aproximadamente 65 espécies, ocorrendo como epífita sobre as árvores que compõem as "florestas nebulares" do topo das montanhas.

No Brasil, o gênero está representado por 12 espécies, distribuídas principalmente nas regiões sudeste e sul em áreas montanhosas da Floresta Atlântica, onde se verifica a maior diversidade para o gênero no Brasil (Tab. 1). Algumas espécies típicas da Floresta Atlântica apresentam uma área de ocorrência mais ampla, estando presentes também na porção sul da cadeia do Espinhaço em Minas Gerais. Destaque-se a presença de quatro espécies distribuídas apenas nas cadeias montanhosas do alto-Amazonas, próximo às fronteiras do Brasil com a Venezuela e as Guianas (Tab. 1).

Nota-se que as espécies deste gênero tendem a ocorrer apenas em ambientes montanhosos de elevadas altitude e umidade relativa do ar, estando ausentes nas regiões Nordeste e Centro-Oeste e Bacia Amazônica (até $500 \mathrm{~m}$ altitude).

Chave para as espécies de Terpsichore

1. Lâminas com crescimento indeterminado, pendentes ou arqueadas; esporângios ciliados

2. Raque com setas castanhas simples e pareadas, e/ou séssil-estreladas

2. Raque apenas com setas castanhas simples

4. Tecido laminar abaxialmente com setas bifurcadas castanho-claras e raque com algumas setas atropurpúreas conspícuas abaxialmente; setas da superfície adaxial pareadas

4. Tecido laminar abaxialmente com setas simples e raque com algumas poucas setas séssil-

7. T. lanigera estreladas, esbranquiçadas, abaxialmente; setas da superfície adaxial simples

5. Segmentos 1-2 vezes tão compridos quanto largos, oblongos a arredondados; sinus geralmente maior que a largura dos segmentos

10. T. senilis

5. Segmentos 3-5 vezes tão compridos quanto largos, oblongos, oblongo-lanceolados ou deltóide-lanceolados; sinus geralmente menor que a largura dos segmentos

6. Escamas do caule estramíneas, ca. 0,3-0,4 cm compr 8. T. reclinata

6. Escamas do caule castanhas, até $0,1 \mathrm{~cm}$ compr. 4. T. cultrata

3. Escamas do caule ausentes 2. T. alfarii

3. Escamas do caule presentes 3. T. bradeana

1. Lâminas com crescimento determinado, geralmente eretas ou apenas levemente arqueadas; esporângios glabros (exceto em $T$. chrysleri)

7. Escamas do caule com a margem ciliada em toda sua extensão

8. Esporângios ciliados; hidatódios sem secreções calcárias 
8. Esporângios glabros; hidatódios geralmente com secreções calcárias

9. T. semihirsuta

7. Escamas do caule sem cílios ou com apenas um único cílio apical

9. Raque e nervuras imersas no tecido laminar (ao menos parcialmente em $T$. gradata), não visíveis

10. Lâmina pinatissecto-pinatífida; escamas do caule $0,3-0,4 \mathrm{~cm}$ compr.

1. T. achilleifolia

10. Lâmina pinatissecta; escamas do caule $0,2-0,25 \mathrm{~cm}$ compr.

6. T. gradata

9. Raque esclerificada, costa e nervuras visíveis

11. Raque, costa, nervuras e tecido laminar conspicuamente setosos; ápice terminando em um segmento terminal flabeliforme

11. T. steyermarkii

11. Raque, costa e margem dos segmentos setosos, tecido laminar com setas apenas nas proximidades dos soros; ápice terminando em um segmento terminal pinatissecto

12. T. taxifolia

1. Terpsichore achilleifolia (Kaulf.) A.R. Sm., Novon 3: 486. 1993.

Polypodium achilleifolium Kaulf., Enum. fil. 116. 1824. Ctenopteris achilleifolia (Kaulf.) J. Sm., Hist. fil. 185. 1875. Grammitis achilleifolia (Kaulf.) R.M. Tryon \& A.F. Tryon, Rhodora 84: 128. 1982. Tipo: BRASIL, "Habitat in Brasilia, Otto communicaviti" (holótipo provavelmente em B).

Fig. 17-19.

Plantas epífitas ou rupícolas. Caule horizontal, curto-reptante, radial, revestido por escamas paleáceas, lanceoladas, 0,3-0,4 cm compr., margem glabra ou raramente com pequenas projeções laterais. Frondes $5-10 \mathrm{~cm}$ compr., eretas a arqueadas; pecíolo até $1,5 \mathrm{~cm}$ compr. e ca. $0,1 \mathrm{~cm}$ diâm., estramíneo, cilíndrico, levemente alado no terço superior, apenas com diminutos tricomas glandulares ramificados em toda sua extensão; lâmina com crescimento determinado, 1,53(4) cm larg., cartácea, lanceolada, pinatissectopinatífida, diminuindo gradativamente para o ápice e para a base, com setas castanhas em toda a extensão da lâmina; raque imersa no tecido laminar, verde a estramínea; segmentos 1-2,5(3) cm compr. e 0,2-0,4 cm larg., lineares, pinatissectos, base assimétrica, decorrente basiscopicamente e cuneada acroscopicamente, ápice agudo a algumas vezes obtuso; indumento formado por setas castanhas simples, uniformes, ca. 0,1-0,15 cm compr., presentes em toda extensão do tecido laminar, especialmente no ápice dos segmentos; sinus ca. de 2-3 vezes mais amplo que a largura dos segmentos; nervuras pinadas, terminando medianamente entre a costa e a margem do segmento, inconspícuas; hidatódios conspícuos na face adaxial da lâmina, formados no ápice

Tabela 1. Distribuição das espécies de Terpsichore A.R. Sm. e Zygophlebia L.E. Bishop nas principais formações montanhosas e florísticas do Brasil.

\begin{tabular}{|c|c|c|c|c|c|c|c|}
\hline Espécie/Formações & $\begin{array}{l}\text { Floresta } \\
\text { Atlântica }\end{array}$ & $\begin{array}{l}\text { Sul da Cadeia do } \\
\text { Espinhaço }\end{array}$ & $\begin{array}{c}\text { Hiléia } \\
\text { sul-baiana }\end{array}$ & $\begin{array}{l}\text { Brejos de } \\
\text { altitude } \\
(\mathrm{NE})\end{array}$ & $\begin{array}{c}\text { Bacia } \\
\text { Amazônica } \\
\text { (até } 500 \text { m.s.m.) }\end{array}$ & $\begin{array}{l}\text { Alto Rio Negro } \\
\text { e Tepuis } \\
\text { ) }\end{array}$ & $\begin{array}{c}\text { Montanhas } \\
\text { do Brasil Central }\end{array}$ \\
\hline
\end{tabular}

\begin{tabular}{|c|c|c|c|}
\hline Terpsichore achilleifolia & $\mathrm{X}$ & $X$ & - \\
\hline T. alfarii & $\mathrm{X}$ & - & - \\
\hline T. bradeana & - & - & - \\
\hline T. chrysleri & $X$ & $X$ & - \\
\hline T. cultrata & - & - & - \\
\hline T. gradata & $\mathrm{X}$ & $\mathrm{X}$ & - \\
\hline T. lanigera & - & - & - \\
\hline T. reclinata & $\mathrm{X}$ & $\mathrm{X}$ & - \\
\hline T. semihirsuta & $\mathrm{X}$ & - & - \\
\hline T. senilis & $\mathrm{X}$ & - & - \\
\hline T. steyermarkii & - & - & - \\
\hline T. taxifolia & $\mathrm{X}$ & - & - \\
\hline Zygophlebia longipilosa & $\mathrm{X}$ & - & - \\
\hline Total & 9 spp. & 4 spp. & - \\
\hline
\end{tabular}

$\begin{array}{llcl}- & - & - & - \\ - & - & - & - \\ - & - & X & - \\ - & - & - & - \\ - & - & X & - \\ - & - & - & - \\ - & - & X & - \\ - & - & - & - \\ - & - & - & - \\ - & - & - & - \\ - & - & - & - \\ - & - & - & - \\ - & - & 4 \text { spp. } & - \\ - & - & & \end{array}$


das nervuras, sem pontos esbranquiçados. Soros arredondados, 3-6 pares por segmento, surgindo no ápice das nervuras; esporângios glabros.

Material examinado: BRASIL. Espírito Santo: Castelo, Forno Grande, 1.500 m, 15/V/1949, Brade 19980 (RB); "Southern slope of Serra do Caparaó", 2.460 m, 30/XI/1926, Mexia 4056 (BM, GH). Minas Gerais: Araponga, Serra do Brigadeiro, Pico do Boné, 26/V/1998, Valente 325 (VIC); Prope Rio Preto, VI/1898, Magalhães 101 (R); Ouro Preto, Serra do Itacolomy, s.d., Badini 80 (OUPR); Serra de Ibitipoca, 24/II/1977, Coons 77-254 (VIC); Alto da Serra da Gramma, Carangola, 20/IV/1935, Kuhlmann 46 (RB). Rio de Janeiro: s.d., Glaziou 2416 (K, RB); Santa Maria Magdalena, XI/1933, Santos Lima 221 (RB); Santo Antônio de Imbé, Pedra da República, 1932, Brade 11630 (R); Serra do Macaé, I/1900, Ule s.n. (R); Terezópolis, 31/III/1917, Sampaio 2057 (R); Petrópolis, estrada para Pati do Alferes, IV/1976, Barcia 983 (R); Serra dos Órgãos, Rio Paquequer, 1.000 m, 13/VII/1940, Brade 16677 (RB); Idem, 1.150 m, VII/1943, B. Lutz 1935 (R); Itatiaia, estrada Nova Km 01, 22/III/1942, Brade 17353 (RB); Idem, Pinheiral, 2.200 m, IX/1934, Brade 14029 (RB); Morro Queimado, 22/I/1948, Brade 18781 (RB); Margem do Rio Funil, próximo à Divisa com São Paulo, 7/XI/1956, Handro 651 (SP, SPF); Bico de Papagaio, VII/1928, Brade 21359 (HB). São Paulo: Serra da Bocaina, 1879, Schwacke s.n. (R); Campos do Jordão, 5-20/II/1937, Campos Porto 3086 (RB); Salesópolis, Estação Biológica de Boracéia, 27/IV/1966, Mattos 13535 (SP); Idem, id., 900 m, 14/II/1999, Labiak 970 (SP); São Paulo, Jardim Botânico, 19/IX/1938, Handro s.n. (SP, SPF); Estação de Campo Grande (via férrea São Paulo-Santos), Estação Biológica, 18/X/1967, Mattos 15102 (SP); Apiahy, V/1885, Puiggari s.n. (SP); Campo Grande, 800 m, XI/1913, Brade 6592 (HB, US); Alto da Serra, 18/VIII/1949, Joly 744 (RB SPF); Cananéia, Ilha do Cardoso, 12/I/1977, TostaSilva 24 (SP). Paraná: Morretes, Serra do Mar, estrada da Graciosa, s.d., Dombrowski 12139 (MBM); Quatro Barras, Morro Sete, 17/XI/1994, Ribas 728 (MBM); Recanto Bela Vista, estrada da Graciosa, entre Quatro Barras e Morretes, 5/X/1996, Dittrich et al. 217 (UPCB); Fazenda Reserva, ca. $85 \mathrm{Km} \mathrm{SW}$ of Guarapuava, forest on slope towards Rio das Torres, s.d., Lindeman \& Hass 5223 (MBM); Morretes, II/1980, Dombrowski 13304 (MBM); Campina Grande do Sul, Escarpa do Pico Paraná, 1.800 m, 2/V/1971, Imaguire 521 (MBM); Serra do Mar, 9/XII/1952, Mattos s.n. (MBM); Estrada Curitiba-
Paranáguá Km 34, 17/X/1961, Pabst 5864 (HB); Santa Catarina: Itajaí, Morro do Baú, 29/I/1948, Reitz C2097 (RB); Campo Alegre, slopes of Morro Erequim, 1.000-1.300 m, 9-10/XII/1956, L.B. Smith \& Klein 8542 (MBM); Garuva, Morro do Cristo, $650 \mathrm{~m}$, 22/XII/1957, Reitz \& Klein 5847 (PACA); Palhoça, Morro do Cambirela, 950 m, 17/XI/1971, Klein \& Bresolin 9928 (PACA); Blumenau, Forest Spitzkopf, 265'ㅇ' 4906'W, 20/III/1952, L.B. Smith \& Reitz 6268 (US). Rio Grande do Sul: Bom Jesus, Aparados, s.d., Dutra 196 (R); Aparados da Serra, Serra da Rocinha, 1.000 m, 3/II/1953, Sehnem 6776 (PACA).

Distribuição geográfica: endêmica das regiões Sudeste e Sul do Brasil.

Terpsichore achilleifolia pode ser facilmente reconhecida por apresentar crescimento determinado, pela lâmina pinatissecto-pinatífida, revestida por setas castanhas simples distribuídas por todo o tecido laminar, e pelas escamas do caule paleáceas, sem cílios.

É bastante frequente nas florestas montanas e altomontanas das regões Sudeste e Sul do Brasil, sendo mais comumente encontrada nas altitudes acima de $1000 \mathrm{~m}$ onde geralmente ocorre como epífita, associada a líquens e briófitas.

2. Terpsichore alfarii (Donn. Sm.) A.R. Sm., Novon 3: 485. 1993.

Polypodium alfarii Donn. Sm., Bot. Gaz. 33: 262. 1902. Tipo: COSTA RICA, Alfaro 73 (holótipo US!). Polypodium oligosorum Mett. ex Kuhn, Linnaea 36: 132. 1869 nom. illeg., non Klotzsch (1847). Síntipos: VENEZUELA, Fendler 208 (B; isossíntipos BM!, BR!, K!); VENEZUELA, Aragua, Colonia Tovar, Moritz 460 (B; isossíntipos $\mathrm{BM}$ !, $\mathrm{K}$ !, fragmento US!); VENEZUELA, Karsten 10 (B).

Plantas epífitas. Caule vertical, curto, radial, sem escamas. Frondes 5-15 cm compr., pendentes; pecíolo até $1 \mathrm{~cm}$ compr. e ca. $0,05 \mathrm{~cm}$ diâm., negro, cilíndrico, levemente alado no terço superior, com setas castanhas ca. 0,1 cm compr.; lâmina com crescimento indeterminado, ca. $1 \mathrm{~cm}$ larg., papirácea, linear a linearlanceolada, pinatissecta, levemente mais estreita na base e diminuindo gradativamente para o ápice; raque esclerificada em ambas as faces, negra; segmentos ca. 0,4 cm larg. e 0,5-0,8 cm compr., deltóides, ápice arredondado, base assimétrica, levemente decorrente basiscopicamente e cuneada acroscopicamente, perpendiculares a levemente oblíquos à raque; indumento formado por setas castanhas simples, ca. $0,08 \mathrm{~cm}$ compr., presentes na raque e margem dos 
segmentos; sinus menor que a largura dos segmentos; nervuras pinadas, 1-(2)-furcadas, terminando medianamente entre a costa e a margem do segmento, inconspícuas ou apenas visíveis na base do segmento; hidatódios inconspícuos. Soros arredondados, $1 \mathrm{ou}$ raramente 2 por segmento, surgindo no ápice das nervuras; esporângios ciliados, cílios 1-2 vezes maiores que o esporângio.

Material examinado: BRASIL. Rio de Janeiro: Serra dos Órgãos, Picada do Rancho Frio, 1.400 m, 30/VIII/1940, Brade 16675 (GH, RB); Santa Maria Magdalena, Águas Paradas 900 m, 5/III/1935, Brade \& Santos Lima 14372 (RB).

Distribuição geográfica: Mesoamérica, Colômbia, Venezuela, Equador, Brasil.

Terpsichore alfarii caracteriza-se por apresentar os segmentos bastante curtos (até $0,8 \mathrm{~cm}$ compr.), deltóides, com setas simples presentes apenas na raque e margem dos segmentos, e pela ausência de escamas no caule.

Terpsichore senilis (Fée) A.R. Sm. é uma das espécies que mais se assemelha a $T$. alfarii, por apresentar crescimento indeterminado e os segmentos também bastante pequenos. No entanto, possui escamas no caule, apresenta o tecido laminar conspicuamente piloso em ambas as faces e a base dos segmentos não decorrentes sobre a raque. Em T. alfarii os segmentos apresentam setas apenas na margem, e são conspicuamente decorrentes no lado basiscópico.

Terpsichore molissima (Fée) A.R. Sm. (da região Mesoamericana) é uma espécie também desprovida de escamas no caule e bastante semelhante à T. alfarii, mas pode ser diferenciada pela presença de setas sobre a superfície da lâmina.

Alguns espécimens de Terpsichore alfarii do Brasil têm sido comumente identificados como Polypodium levelleianum Desv. Esse nome, no entanto, aplica-se a Terpsichore elastica (Bory ex Willd.) A.R. Sm., uma espécie africana.

Terpsichore alfarii parece ser uma espécie bastante rara no Brasil, tendo sido registrada apenas no Estado do Rio de Janeiro, onde ocorre como epífita nas florestas da Serra dos Órgãos.

3. Terpsichore bradeana Labiak, Brittonia 52(3): 251. 2000.

Tipo: BRASIL. Roraima: Serra dos Surucucus, 0242-47'N, 63³3-36'W, 19/II/1969, Prance 10075 (holótipo INPA!; isótipos K!, NY!, R!).

Fig. 20-22.
Plantas epífitas. Caule curto-escandente, dorsiventral, com escamas paleáceas, deltóides, ca. $0,2 \mathrm{~cm}$ compr., com cílios na margem e centro da escama. Frondes 20-35 cm compr., pendentes; pecíolo 1-3 cm compr. e ca. 0,05 diâm., negro, delgado, cilíndrico, com setas estramíneas conspícuas, ca. 0,2 cm compr.; lâmina com crescimento indeterminado, 1,5-2 cm larg., papirácea, linear-lanceolada, pinatissecta, com os segmentos basais levemente menores que os demais; raque esclerificada, negra a castanho-escura; segmentos 0,3-0,4 cm larg. e 0,7-1,2 cm compr., linear-deltóides, base levemente assimétrica, ápice obtuso, perpendiculares a levemente reclinados à raque; indumento formado por setas castanhas simples, presentes em ambas as faces da raque e tecido laminar, e tricomas ramificados presentes na raque e alguns poucos no tecido laminar; sinus igual ou maior que a largura dos segmentos; nervuras pinadas, terminando submarginalmente entre a costa e a margem do segmento, inconspícuas. Soros arredondados, 2-4(5) pares por segmento, surgindo no ápice das nervuras; esporângios ciliados, os cílios ca. 1,5 vezes o tamanho do esporângio.

Material examinado: VENEZUELA. Bolívar: Cerro Venamo, Cerca de los limites con la Guayana Inglesa, 1.220-1.275 m, 6-7 Feb 1964, Steyermark \& Dunsterville 92828 (parátipo US!).

Distribuição geográfica: Venezuela, Brasil.

Terpsichore bradeana caracteriza-se principalmente por apresentar apenas setas simples sobre a raque, margem e superfície do tecido laminar, e pelas escamas do caule ca. 0,2 cm compr., com cílios marginais menores que o tamanho das escamas.

Terpsichore alsophilicola (Christ) A.R. Sm. é uma das espécies semelhantes, podendo ser diferenciada por apresentar escamas até $0,1 \mathrm{~cm}$ compr., com os cílios geralmente duas vezes maiores que o tamanho das escamas.

Terpsichore cultrata (Bory ex Willd.) A.R. Sm. é outra espécie que apresenta a forma da fronde e dos segmentos bastante semelhantes a $T$. bradeana, podendo ser distinguida pela presença de setas ramificadas na raque e margem dos segmentos.

Terpsichore bradeana é uma espécie endêmica das regiões montanhosas na fronteira do Brasil com a Venezuela, crescendo geralmente como epífita nas florestas de altitude, sendo conhecida apenas pela coleção-tipo.

4. Terpsichore chrysleri (Copel.) A.R. Sm., Novon 3(4): 486. 1993. 
Ctenopteris chrysleri Copel., Philipp. J. Sci. 84: 448. 1956. Grammitis crhysleri (Copel.) Proctor, Brit. Fern Gaz. 9: 218. 1965. Tipo: JAMAICA, parish of Portland, from along trail betwen Morces Gap and Vinegar Hill, Maxon 1524 (holótipo US!).

Polypodium repandum Fée, Crypt. vasc. Br. 1: 87, t. 29, f. 1. 1869. Síntipos: BRASIL. "Habitat in brasilia fluminensi", Glaziou 2409 et Serra do Couto (P; isossíntipo BR!), Glaziou 3170 (P; fragmento NY!), nom. illeg., non Loureiro (1790), Swartz (1802), nec Vahl (1807).

Polypodium confluens Fée, Crypt. vasc. Br. 1: 89, t. 26, f. 3. 1869. Tipo: BRASIL, "Habitat in Brasilia fluminensi" Glaziou 2413 (holótipo P), ex descr. et icon.

Fig. 35-37.

Plantas epífitas. Caule horizontal, curto-reptante, dorsiventral, com escamas castanhas, deltóide-lineares, 5-6 cm compr., margens com cílios em toda sua extensão. Frondes 30-50 cm compr., pendentes; pecíolo 10-14 cm compr. e ca. 0,1 cm diâm., castanho, cilíndrico, com setas castanhas conspícuas, ca. $0,2 \mathrm{~cm}$ compr.; lâmina com crescimento determinado, $3-6 \mathrm{~cm}$ larg., cartácea, deltóide-lanceolada, pinatissecta, diminuindo abruptamente para a base e gradativamente para o ápice; raque esclerificada abaxialmente, negra, adaxialmente recoberta pelo tecido lâminar (ao menos na terço apical); segmentos 2,5-4(5) $\mathrm{cm}$ compr. e 0,4-0,7 cm larg., deltóide-lineares, base assimétrica e ápice obtuso, perpendiculares ou levemente oblíquos a raque; indumento formado por setas castanhas simples, ca. 0,1 cm compr., presentes em ambas as faces da raque e na margem dos segmentos, e tricomas glandulares diminutos, ramificados, presentes na raque e tecido laminar abaxialmente; sinus igual ou até 1,5 vezes maior que a largura dos segmentos; nervuras pinadas, 1-2-furcadas, terminando próximas à margem dos segmentos; hidatódios inconspícuos, localizados no ápice das nervuras, sem pontos esbranquicados. Soros arredondados, formados no ápice das nervuras secundárias, medianamente na lâmina; esporângios ciliados, cílios aproximadamente do mesmo tamanho que o esporângio.

Material examinado: BRASIL. Espírito Santo: Castelo, Braço Sul, 9/VIII/1948, Brade 19208 (RB); Limoeiro, Santa Maria, 17/V/1946, Brade 18281 (RB). Minas Gerais: Ouro Preto, Tripuí, 1912, Araújo s.n. (R); Idem, Manso, s.d., Damazio s.n. (R, RB, OUPR). Rio de Janeiro: Santo Antônio do Imbé, Pedra da República, 1.000 m, IV/1932, Brade \&
Santos Lima 11632 (BM, R); Santa Maria Magdalena, Águas Paradas, 900 m, 2/III/1935, Brade \& Santos Lima 14368 (RB); Organ Mountain, s.d., Miers 69 (K). São Paulo: Salesópolis, 29/IV/1958, Handro 763 (SP, SPF, US); Estação Biológica de Boracéia, 14/II/1999, Labiak 982 (SP); Iguape, Serra de Paranapiacaba, XI/1925, Brade 8398 (HB, R).

Distribuição geográfica: Antilhas, Mesoamérica, Colômbia, Venezuela, Equador, Peru, Bolívia, Brasil.

Terpsichore chrysleri caracteriza-se principalmente por apresentar a lâmina abruptamente reduzida para a base, pecíolo bastante longo (10-14 cm compr.), e por apresentar hábito pendente, embora possua crescimento apical das frondes determinado.

Terpsicore asplenifolia (L.) A.R. Sm. é uma espécie bastante semelhante, podendo ser distinguida principalmente por apresentar as escamas menores (até $0,2 \mathrm{~cm}$ compr.), a lâmina geralmente mais estreita (com até $4 \mathrm{~cm}$ larg.) e as nervuras apenas 1-furcadas. Em T. chrysleri as escamas variam de 0,4-0,6 cm compr., a lâmina pode chegar até $6 \mathrm{~cm}$ larg. e as nervuras frequentemente são 2-furcadas.

No Brasil ocorre na região Sudeste em altitudes que variam de 900 a $1.600 \mathrm{~m}$, geralmente como epífita sobre troncos de Cyatheaceae.

5. Terpsichore cultrata (Bory ex Willd.) A.R. Sm., Novon 3(4): 486. 1993.

Polypodium cultratum Bory ex Willd., Sp. pl. 5: 187. 1810. Ctenopteris cultrata (Bory ex Willd.) Copel., Gen. Fil. 219. 1947. Grammitis cultrata (Bory ex Willd.) Proctor, Rhodora 63: 35. 1961. Xiphopteris cultrata (Bory ex Willd.) Schelpe, Bol. Soc. Brot. ser. 2, 41: 217. 1967. Tipo: JAMAICA. Swartz (holótipo B; isótipos B-W 19674; fotos GH!, US!).

Fig. 29.

Plantas epífitas. Caule vertical, curto-reptante, com escamas castanho-escuras, deltóide-lanceoladas, ca. $0,1 \mathrm{~cm}$ compr., margem com cílios esbranquiçados. Frondes 15-60 cm compr., pendentes; pecíolo 1-3 cm compr. e ca. 0,1 cm diâm., castanho-escuro, delgado, densamente setoso, com setas ca. 0,2 cm compr.; lâmina com crescimento indeterminado, 2-3(4) cm larg., papirácea, linear-lanceolada, pinatissecta, diminuindo gradativamente para o ápice e para a base; raque esclerificada, negra a castanho-escura; segmentos 1-2,5 cm compr. e 0,3-0,5 cm larg., deltóidelineares, base simétrica ou ligeiramente assimétrica, não ou apenas ligeiramente cuneada acroscopicamente, ápice obtuso, perpendiculares ou apenas levemente 
oblíquos à raque; indumento formado por setas castanhas simples presentes em ambas as faces da raque e superfície laminar, setas séssil-estreladas, esbranquiçadas, presentes apenas na raque abaxialmente, e tricomas hialinos ramificados presentes na raque; sinus menor ou geralmente com a mesma largura dos segmentos; nervuras pinadas, 1-furcadas, terminando submediamente entre a costa e a margem dos segmentos, inconspícuas ou visíveis apenas na base dos segmentos; hidatódios inconspícuos, sem pontos esbranquiçados. Soros arredondados, 3-5(7) pares por segmento, surgindo no ápice das nervuras; esporângios conspicuamente ciliados, os cílios $1-1,5$ vezes o comprimento do esporângio.

Material examinado: BRASIL. Amazonas: São Gabriel da Cachoeira, Cordilheira do Pico da Neblina, 2.000 m, 17/X/1977, Rodrigues 9877 (INPA); Monte Roraima, on the ledge above Rondon Camp, 1/XII/1927, Tate 465 (NY, US).

Distribuição geográfica: Mesoamérica, Antilhas, Colômbia, Venezuela, Equador, Peru, Bolívia, Brasil.

Terpsichore cultrata é uma espécie com ampla variação na forma e densidade de pubescência sobre a lâmina. Pode ser caracterizada por apresentar as setas da raque e da margem dos segmentos simples e/ou ramificadas (estreladas), e as escamas do caule com até $0,1 \mathrm{~cm}$ compr., densamente ciliadas na margem.

Terpsichore cultrata foi por longo tempo considerada como uma espécie de ampla distribuição geográfica, ocorrendo até mesmo no leste da África e Madagascar (Copeland 1956; Proctor 1985; Smith 1993). No entanto, estudos mais recentes (Smith 1995) têm considerado os materiais do Neotrópico e Africanos como espécies distintas, apesar da grande afinidade morfológica compartilhada por ambas.

Terpsichore reclinata (Brack.) Labiak é uma das espécies mais semelhantes a T. cultrata, podendo ser diferenciada pelas características apresentadas na chave (ver comentários adicionais em Labiak 2000).

6. Terpsichore gradata (Baker) A.R. Sm., Novon 3(4): 486. 1993.

Polypodium gradatum Baker, Fl. Bras. 1(2): 513. 1870. Polypodium hirsutulum Fée, Crypt. vasc. Br. 1: 87. 1869, nom illeg., non Forst (1786). Ctenopteris gradata (Baker) Copel., Philipp. J. Sci. 84(4): 437. 1956. Grammitis gradata (Baker) R. M. Tryon \& A. F. Tryon, Rhodora 84(837): 128. 1982. Tipo: BRASIL. Rio de Janeiro. "Habitat prope Rio de Janeiro", Glaziou 2460 (holótipo P; isótipo BM!, foto GH!).
Polypodium schwackei Christ in Schwacke, Pl. Nov. Mineiras 2: 20. 1900. Ctenopteris schwackei (Christ) Copel., Philipp. J. Sci. 84(4): 438. 1956. Tipo: BRASIL. Minas Gerais. "Habitat Serra de Ouro Preto", Schwacke 9488 (holótipo P; isótipo RB!).

Fig. 33-34.

Plantas epífitas ou rupícolas. Caule vertical, curtoescandente, dorsiventral, com escamas paleáceas, deltóide-lanceoladas, 0,2-0,25 cm compr., margem glabra, ou raramente com pequenas projeções das células laterais. Frondes 4-15(18) cm compr., eretas a levemente arqueadas; pecíolo 1-3(5) cm compr. e ca. $0,1 \mathrm{~cm}$ diâm., castanho-escuro, cilíndrico, levemente alado na porção distal pela base da lâmina decorrente, com setas castanhas conspícuas ca. 0,1-0,15 cm compr.; lâmina com crescimento determinado, 1,5-2,5(3) cm larg., cartácea, lanceolada a linear-lanceolada, pinatissecta, diminuindo gradativamente para o ápice $\mathrm{e}$ para a base, formando uma ala na porção distal do pecíolo; raque imersa no tecido lâminar em ambas as faces, levemente sulcada adaxialmente; segmentos 0,3-0,8 cm compr. e 0,25-0,3(0,4) cm larg., deltóides, a base simétrica e o ápice arredondado, levemente oblíquos à raque; indumento formado por setas castanhas simples, ca. 0,1 cm compr., presentes em ambas as faces da lâmina e raque; sinus menor que a largura dos segmentos; nervuras pinadas, 1-furcadas, até 4(5) pares por segmento, terminando medianamente entre a costa e a margem do segmento, inconspícuas; hidatódios conspícuos, sem pontos esbranquiçados. Soros arredondados, surgindo medianamente sobre as nervuras; esporângios glabros.

Material examinado: BRASIL. Minas Gerais: Mariana, Serra do Frazão, 1.500 m, 3/VIII/1998, Labiak 719 (SP); Ouro Preto, Serra do Itacolomy, 1934, Badini 79 (RB); Idem, id., 1936, Badini 101 (RB); Ouro Preto, 11/VI/1902, Damazio 1656 (BM, RB); Araponga, Serra do Brigadeiro, 26/V/1998, Valente 340 (VIC); Carangola, Serra da Grama, 11/IX/1987, Leoni 73 (UEC). Espírito Santo: Santa Tereza, Res. Mello-Leitão, IV/1972, Lagasa 49 (R); Castelo, Braço Sul, 6/VIII/1948, Brade 19156 (RB); Southern slope of Serra do Caparaó, 1.550-2.460 m, 30/XI/1929, Mexia 4052 (BM, GH, US). Rio de Janeiro: Santa Maria Magdalena, Alto da República, 1.600 m, 3/III/1935, Brade \& Santos Lima 14363 (RB); Nova Friburgo, Subida da Caledônia, 14/V/1951, Capell s.n. (RB); Terezópolis, Comary, 1.200 m, 14/XI/1924, Brade 10002 (HB, R); Serra dos Órgãos, Pedra do Frade, 1.400 m, 20/VIII/1940, Brade 16610 (RB); Tijuca, X/1928, Brade 21340 (HB); Resende, Parque Nacional do Itatiaia, $1.780 \mathrm{~m}$, 
30/VII/1966, Eiten \& Eiten 7647 (SP); Itatiaia, Matto, Vicinity of Macieiras, 1.960 m, 9/I/1929, Smith s.n. (GH); Gericinó, 800 m, 2/V/1931, Brade 31617 (R); Itatiaia, Serra do Taquaral, $1.300 \mathrm{~m}, 18 / \mathrm{II} / 1945$, Brade 17461 (RB); Bico de Papagaio, 12/VI/1941, Brade 16824 (RB). São Paulo: Parque Estadual da Serra do Mar, Cunha, 16/XII/1996, Salino 2927 (BHCB, SP); Campos do Jordão, 20/VI/1981, Ranal 86 (HUFU); Alto da Serra, 2/II/1908, Usteri s.n. (SPF); Idem, III/1913, Tamandaré 483 (RB); Boracéia, 16/I/1941, Lima s.n. (RB); Paraná: Quatro Barras, Serra de Mãe Catira, Vertentes do Rio do Corvo, 18/III/1991, Oliveira 95 (SJRP); Morretes, Serra do Marumbi, Pico do Olimpo, 1.500 alt., 13/XI/1970, Hatschbach 25384 (MBM, PACA); Santa Catarina: Morro da Tromba, 700 m, 1906, Schmalz s.n. (PACA, R).

Distribuição geográfica: Endêmica das regiões Sudeste e Sul do Brasil.

Terpischore gradata pode ser reconhecida pelas escamas paleáceas, glabras, seu tamanho moderado (até $15 \mathrm{~cm}$ compr.), e pela presença de setas castanhas em todo o tecido laminar.

O tipo de Polypodium schwackei Christ, bem como de diversos espécimes provenientes do limite norte de distribuição de Terpsichore gradata, apresentam tamanho bastante reduzido (até $8 \mathrm{~cm}$ compr.) e raque esclerificada em pelo menos $2 / 3$ de sua extensão. Esses caracteres, no entanto, devem ser considerados apenas como uma variação clinal da espécie, não sendo suficiente para elegê-las como táxons distintos.

Terpsichore staheliana (Posth.) A.R. Sm. é uma espécie que apresenta a forma da lâmina e dos segmentos bastante semelhante a $T$. gradata. No entanto, pode ser distinguida por apresentar os esporângios ciliados e uma cobertura conspicuamente densa de setas em toda a superfície da lâmina.

Terpsichore gradata é uma espécie relativamente comum na Floresta Atlântica brasileira, ocorrendo como epífita ou rupícola em altitudes que variam de 1.000 a $2.000 \mathrm{~m}$

7. Terpsichore lanigera (Desv.) A.R. Sm., Novon 3(4): 487. 1993.

Polypodium lanigerum Desv., Ges. Naturf. Freund. Berlin Mag. 5: 316. 1811. Ctenopteris lanigera (Desv.) Copel., Philipp. J. Sci. 84: 420. 1956. Grammitis lanigera (Desv.) C.V. Morton, Contrib. U.S. Natl. Herb. 38: 105. 1967. Xiphopteris lanigera (Desv.) Crabbe, Brit. Fern Gaz. 9: 319. 1967. Tipo: PERU. Dombey, Herb. Jussieu 1099 (holótipo P, fotos $\mathrm{BM}$ !, NY!).
Polypodium sericeolanatum Hook., Sp. fil. 4: 221. 1864. Ctenopteris sericeolanata (Hook.) Copel., Philipp. J. Sci. 84: 420. 1956. Grammitis sericeolanata (Hook.) Proctor, Rhodora 63: 35. 1961. Lectótipo (designado por Morton, Contr. U.S. Natl. Herb. 38: 105. 1967.): EQUADOR. Ravines of Pichincha, Jameson 235 (K!, fragmento US!).

Fig. 30.

Plantas epífitas. Caule vertical, dorsiventral, com escamas paleáceas, lanceoladas, ca. 0,2-0,3 cm compr., densamente ciliadas na margem. Frondes $15-60 \mathrm{~cm}$ compr., pendentes; pecíolo 1-3 cm compr. e ca. 0,05-0,1 cm diâm., castanho-escuro, delgado, cilíndrico, com setas castanhas conspícuas, ca. $0,15-0,25 \mathrm{~cm}$ compr.; lâmina com crescimento indeterminado, 1,5-3(4) cm larg., papirácea, linear-lanceolada, pinatissecta, diminuindo gradativamente para o ápice e para a base; raque esclerificada, negra a castanho-escura; segmentos 1,2-2,5 cm compr. e 0,3-0,5 cm larg., oblongos a oblongo-lanceolados, base conspicuamente assimétrica, decorrente basiscopicamente e levemente cuneada acroscopicamente, ápice obovado a obtuso, perpendiculares a levemente oblíquos à raque; indumento formado por setas castanho-claras, bifurcadas, em ambas as faces do tecido laminar e raque, e setas ramificadas atropurpúreas conspícuas, presentes apenas na raque; sinus menor que a largura dos segmentos; nervuras pinadas, 1-furcadas, terminando medianamente entre a costa e a margem do segmento, inconspícuas; hidatódios inconspícuos, sem pontos esbranquiçados. Soros arredondados, 3-6(8) pares por segmento, surgindo no ápice das nervuras; esporângios conspicuamente ciliados, os cílios 1-1,5 vezes o tamanho do esporângio.

Material examinado: BRASIL. Roraima: Igarapé Arapopó, fronteira Brasil-Guiana, IX/1927, Luetzelburg 21482 (R pro-parte); Monte Roraima, Rondon Camp., 3/XII/1927, Tate 501 (NY).

Distribuição geográfica: Costa Rica, Panamá, Pequenas Antilhas, Colômbia, Venezuela, Suriname, Equador, Peru, Bolívia, Brasil.

Terpsichore lanigera é uma espécie bastante característica pela sua densa cobertura de setas esbranquiçadas sobre a raque e tecido laminar mescladas com algumas setas séssil-estreladas, atro-purpúreas, conspícuas, distribuídas sobre a raque. É uma espécie bastante semelhante à $T$. cultrata, que difere por apresentar as escamas do caule nunca maiores que $0,1 \mathrm{~cm}$ compr., e pelas setas da superfície adaxial da lâmina nunca pareadas ou estreladas. 
No Brasil esta espécie ocorre apenas nos limites fronteiriços ao norte do País, como epífita nas florestas de altitude.

8. Terpsichore reclinata (Brack.) Labiak, Brittonia 52(3): 253. 2000.

Polypodium reclinatum Brack., Expl. Exp.16: 11. 1854. Ctenopteris reclinata (Brack.) Copel., Philipp. J. Sci. 84: 424. 1956. Tipo: BRASIL. Rio de Janeiro. Serra dos Órgãos, Wilkes Exped. 161 (holótipo US!, foto SP!; isótipos $\mathrm{K}$ !, NY!).

Polypodium ciliare Fée, Crypt. vasc. Br. 1: 94, t. 27, f. 2, 1869. Ctenopteris ciliaris (Fée) Copel., Philipp. J. Sci. 84: 425. 1956. Tipo: BRASIL. Rio de Janeiro. "Habitat in Brasilia fluminensis" Glaziou 961 (holótipo P; isótipo BR!; fragmento NY!).

Polypodium ovalescens Fée, Crypt. vasc. Br. 1: 94, t. 27, f. 3. 1869. Tipo: BRASIL. "Habitat in Brasilia fluminensi” Glaziou 1722 (holótipo P; isótipo BR!).

Fig. 26-28.

Plantas epífitas. Caule vertical, subereto, dorsiventral, com escamas paleáceas, lanceoladas, ca. 0,3-0,4 cm compr., densamente ciliadas na margem e alguns poucos cílios surgindo sobre as células centrais. Frondes 10-60 cm compr., pendentes; pecíolo 1-3(4) cm compr. e ca. 0,05-0,1 cm diâm., castanhoescuro, delgado, cilíndrico, com setas castanhas conspícuas, ca. 0,15-0,25 cm compr.; lâmina com crescimento indeterminado, 1,5-3(4) cm larg., papirácea, linear-lanceolada, pinatissecta, diminuindo gradativamente para o ápice e para a base; raque esclerificada, negra a castanho-escura; segmentos 1,2-2,5 cm compr. e 0,3-0,5 cm larg., oblongos a oblongo-lanceolados, base conspicuamente assimétrica, decorrente basiscopicamente e fortemente cuneada acroscopicamente, ápice obovado a obtuso, perpendiculares a levemente oblíquos à raque; indumento formado por setas castanhas simples presentes no tecido laminar e raque, e setas estreladas e tricomas hialinos ramificados presentes apenas na raque; sinus menor que a largura dos segmentos; nervuras pinadas, 1-furcadas, terminando medianamente entre a costa e a margem do segmento, inconspícuas ou visíveis apenas na base dos segmentos; hidatódios inconspícuos, sem pontos esbranquiçados. Soros arredondados, surgindo no ápice das nervuras; esporângios conspicuamente ciliados, os cílios 1-1,5 vezes o tamanho do esporângio.

Material examinado: BRASIL. Espírito Santo: Castelo, Braço Sul, 9/VIII/1948, Brade 19207 (RB). Minas Gerais: Serra do Caraça, 5/IV-5/V/1885, Vainio 33253 (GH); Serra do Cipó, Km 152 da Estrada da Conceição, 1.280 m, 30/VII/1950, Duarte 2729 (RB); Ouro Preto, Itacolomy, s.d., Baeta s.n. (OUPR); Pedra do Papagaio, XI/1897, Silveira 87 (R); Mariana, Serra do Frazão, 1.500 m, 3/VIII/1998, Labiak 713 (SP). Rio de Janeiro: s.d., Glaziou 2417 (K); Nova Friburgo, s.d., Glaziou s.n. (R); Santo Antonio de Imbé, Pedra da República, 1.300 m, IV/1932, Brade \& Santos Lima 11624 (R); Santa Maria Magdalena, Águas Paradas, VI/1933, Santos Lima 161 (RB); Nova Friburgo, Pico da Caledônia, 14/V/1951, Capell s.n. (RB); Terezópolis, 1873, Glaziou s.n. (R); Parque Nacional da Serra dos Órgãos, 1.100 m, IV/1943, $B$. Lutz 1977 (R); Soberbo, estrada Terezopolis-Bahia, 15/VI/1968, Sucre 3166 (RB); Petrópolis, Quitandinha, 18/I/1940, A. Lutz 2318 (R); Idem, 18/I/1940, Curtis 06 (R); Serra dos Órgãos, Lerbier du Brésil, 1833, Vauthier 588 (GH); Mauá, Serra da Mantiqueira, 1.500-1.800 m, III/1913, Toledo 463 (RB); Itatiaia, Rio Bonito, 30/IV/1932, Campos Porto 2266 (RB); Serra da Bocaina, I/1931, B.Lutz 727 (R). São Paulo: Bocaina, III/1894, Loefgren \& Edwall s.n. (SP); Salesópolis, Boracéia, 19/XII/1940, Santos Lima \& L. da Silva s.n. (RB); Alto da Serra, $1.200 \mathrm{~m}$, 14/VII/1912, Brade 5237 (HB); Serra do Cubatão, 7/XI/1901, Schwacke 14986 (RB); Rio Grande, 1906, Wacket 102 (GH, R, RB); “Ad Apiahy”, VI/1879, Puiggani s.n. (RB); Ipiranga, 23/IX/1922, Kuhlmann s.n. (RB); Iguape, Serra de Paranapiacaba, X/1925, Brade 8484 (HB); Santo André, Paranapiacaba, 8/IX/1973, Windisch 463 (HRCB); Serra de Itatins, 900 m, III/1924, Brade 8316 (US). Paraná: Carambehy, Campos Gerais, 1874, Glaziou \& Schwacke s.n. (R); Ipiranga, 3/II/1904, Dusén s.n. (R); Monte Alegre, 1.200 m, VIII/1904, Dusén 3384 (R); Estrada Curitiba-Paranaguá Km 34, 17/X/1961, Pereira 6057 (RB); Piraquara, Rio Taquary, 30/VI/1946, Hatschbach 318 (MBM, RB); Véu de Noiva, 850 m, 1/XII/1970, Hatschbach 25707 (MBM, US); Mananciais da Serra, 7/II/1968, Dombrowski 2886 (MBM); Curitiba, Roça Nova, 27/XI/1903, Dusén 2290 (R); Campina Grande do Sul, Serra do Capivari Grande, 1.800 m, 6/VIII/1961, Hatschbach 8232 (MBM); Serra Ibitiraquire, 1.600 m, 25/VI/1969, Hatschbach 22221 (MBM); Antonina, São Sebastião, 800 m, 11/IX/1970, Hatschbach 24702 (MBM, NY, PACA); Morretes, Estrada da Graciosa, Alto da Serra, 850-900 m, 30/VII/1968, Hatschbach 19549 (PACA); Corvo, Alto da Serra do Mar, 935 m, 10/IV/1948, Tessman s.n. (MBM); Estrada da Graciosa, Trilha dos Jesuítas, 12/I/1964, Hatschbach 10888 (MBM, PACA); Quatro Barras, Rio Taquari, 21/II/1967, 
Hatschbach 16022 (MBM). Santa Catarina: Antinha, Biguaçú, 500 m, 4/III/1943, Reitz 237 (PACA); Blumenau, Spitzkopf, 265' S, 4906’ W, 20/III/1952, Smith \& Reitz 6269 (R, RB, US); Serra do Mar, 1874, Schwacke 831 (RB); Bom Retiro, Campo dos Padres, 1.700 m, 17/I/1957, Sehnem 6973 (PACA); Rancho Queimado, 15/X/1946, Rohr 1976 (RB); Itajaí, Morro do Baú, 29/I/1948, Reitz C2099 (RB); Fachinal, Biguassú, 18/I/1945, Reitz 1379 (BM, K, R, RB); Ibirama, Horto Florestal, 12/I/1956, Smith \& Klein 7560 (R, US); Joinvile, estrada Dona Francisca, 21/VI/1957, Reitz \& Klein 4452 (HB). Rio Grande do Sul: São Francisco de Paula, Serra do Faxinal, 1.000 m, 1/XII/1950, Sehnem 5091 (PACA).

Distribuição geográfica: Endêmica das regiões Sudeste e Sul do Brasil.

Terpsichore reclinata caracteriza-se por apresentar os segmentos oblongos, com a base conspicuamente assimétrica, fortemente cuneada acroscopicamente e decorrente basiscopicamente, e as escamas do caule com cerca de 0,2-0,3 cm compr. Terpsichore cultrata é uma espécie bastante semelhante, podendo ser diferenciada pelos segmentos simétricos ou apenas levemente simétricos na base, e as escamas nunca maiores que $0,1 \mathrm{~cm}$ compr. (comentários adicionais em Labiak 2000).

É uma espécie endêmica das regiões Sul e Sudeste do Brasil, ocorrendo com bastante frequência nas regiões montanhosas da floresta atlântica brasileira, como epífita.

9. Terpsichore semihirsuta (Klotzsch) A.R. Sm., Novon 3(4): 488. 1993.

Polypodium semihirsutum Klotzsch, Linnaea 20: 379. 1847. Ctenopteris semihirsuta (Klotzsch) Copel., Philipp. J. Sci. 84: 450. 1956. Grammitis semihirsuta (Klotzsch) C.V. Morton, Contr. U.S. Natl. Herb. 38: 113. 1967. Tipo: PERU. Panatahuas, Herb. Ruiz 9 , (holótipo B; isótipo US!).

Polypodium gratum Fée, Crypt. vasc. Br. 1: 242, t. 76, f. 2. 1869. Tipo: BRASIL. Rio de Janeiro. "Habitat in Brasilia fluminensi, Serra dos Orgãos", Glaziou 3336 (holótipo P; isótipo US!).

Fig. 38.

Plantas terrestres ou rupícolas. Caule horizontal, curto-reptante, dorsi-ventral, com escamas castanhoavermelhadas, deltóide-lanceoladas, 0,6-0,8 cm compr., com cílios marginais. Frondes $45-60 \mathrm{~cm}$ compr., eretas; pecíolo 8-10 cm compr. e ca. 0,15-0,2 cm diâm., castanho-escuro, com setas estramineas conspícuas, ca. 0,15-0,2 cm compr.; lâmina com crescimento determinado, 5-6 cm larg., cartácea, linear-lanceolada, pinatissecta, diminuindo gradativamente para o ápice e para a base, os segmentos basais reduzidos a auriculas; raque esclerificada em ambas as faces, castanho-escura; segmentos 2,5-3,5 cm compr. e 0,5-0,6 cm larg., deltóide-lanceolados, base simétrica e ápice arredondado, perpendiculares à raque; indumento formado por setas castanhas simples, ca. $0,1 \mathrm{~cm}$ compr., presentes em ambas as faces da raque e no tecido laminar apenas na margem, algumas vezes ausentes em materiais antigos; sinus frequentemente mais estreito que a largura dos segmentos; nervuras pinadas, 1-furcadas, 7-9 pares por segmento, terminando submarginalmente entre a costa e a margem do segmento, visíveis em ambas as faces; hidatódios conspícuos, esbranquiçados. Soros arredondados, formados sobre o ápice das nervuras; esporângios glabros.

Material examinado: BRASIL. Rio de Janeiro: Serra dos Órgãos, Pedra Chapadão, 1.950 m, 1/V/1932, Brade 9644 (HB); Terezópolis, Pedra Assú, 2.100 m, 30/XI/1929, Brade 9509 (R).

Distribuição geográfica: México, Mesoamérica, Jamaica, Hispaniola, Colômbia, Venezuela, Equador, Peru, Bolívia, Brasil.

Terpsichore semihirsuta caracteriza-se principalmente por apresentar as escamas do caule castanhoavermelhadas, marginalmente ciliadas, ca. $0,6-0,8 \mathrm{~cm}$ compr., e pela costa e nervuras visíveis em ambas as faces da lâmina.

Terpsichore taxifolia (L.) A.R. Sm. é uma das espécies mais semelhantes, podendo ser distinguida por apresentar as escamas do caule glabras, com apenas um cílio apical.

Terpsichore semihirsuta é um dos poucos representantes de Grammitidaceae com hábito terrestre, sendo uma espécie de ocorrência esporádica no Brasil, com registros até o momento apenas para o Estado do Rio de Janeiro.

10. Terpsichore senilis (Fée) A.R. Sm., Novon 3(4): 488. 1993.

Polypodium senile Fée, Mém. Fam. Foug. 5: 60, t. 25, f. 1. 1857. Ctenopteris senilis (Fée) Copel., Philipp. J. Sci. 84(4): 398. 1956. Grammitis senilis (Fée) C.V. Morton, Contr. U.S. Natl. Herb. 38: 103. 1967. Tipo: COLÔMBIA. norte de Santander, Schlim 364 (holótipo P).

Polypodium subflabelliforme Rosenst., Fedde Repert. 7: 306. 1909. Tipo: EQUADOR. Cerro de Abitayua, Spruce 5271 (holótipo B; isótipos BM!, K!). 
Plantas epífitas. Caule vertical, curto-escandente, dorsiventral, com escamas paleáceas, lanceoladas, ca. $0,1 \mathrm{~cm}$ compr., densamente ciliadas na margem, cílios geralmente maiores que o comprimento da escama. Frondes 8-15 cm compr., pendentes; pecíolo 1-2(3) cm compr. e ca. 0,05 cm diâm., castanho-escuro, delgado, cilíndrico, com setas castanho-claras conspícuas, ca. 0,15 cm compr.; lâmina com crescimento indeterminado, 0,6-1,5 cm larg., papirácea, linear-lanceolada, pinatissecta, diminuindo gradativamente para o ápice e para a base; raque esclerificada, negra a castanhoescura; segmentos 0,3-0,5 cm compr. e 0,2-0,3 cm larg., oblongos a arredondados, base assimétrica, decorrente basiscopicamente e cuneada acroscopicamente, ápice arredondado, perpendiculares a levemente oblíquos à raque; indumento formado por setas castanho-claras simples ou algumas vezes pareadas presentes no tecido laminar e raque, e tricomas hialinos ramificados presentes apenas na raque; sinus geralmente maior que a largura dos segmentos; nervuras pinadas, 1-furcadas, terminando medianamente entre a costa e a margem do segmento, inconspícuas ou visíveis apenas na base dos segmentos; hidatódios inconspícuos, sem pontos esbranquiçados. Soros arredondados, surgindo no ápice das nervuras; esporângios conspicuamente ciliados, os cílios 1-1,5 vezes o tamanho do esporângio.

Material examinado: BRASIL. Amazonas: Prope Darra, Prov. Rio Negro, VII/1851, Spruce 1720 (BM). São Paulo: Campos do Jordão, Parque Estadual (Horto Florestal), 1/X/1988, Salino 555 (BHCB, UC).

Distribuição geográfica: Mesoamérica, Jamaica, Hispaniola, Colômbia, Venezuela, Equador, Peru, Bolívia, Brasil.

Terpsichore senilis caracteriza-se por apresentar as frondes estreitas (até 1,5 cm larg.) e pendentes, e os segmentos oblongos a arredondados, com a base assimétrica, decorrente basiscopicamente e cuneada acroscopicamente, e pelas escamas do caule com cílios geralmente maiores que o comprimento das mesmas.

Terpsichore reclinata (Brack.) Labiak é uma das espécies mais semelhantes, podendo ser diferenciada por apresentar frondes mais amplas (até 3(4) cm larg.) e escamas do caule $0,2-0,3 \mathrm{~cm}$ compr., ciliadas, com cílios nunca maiores que o tamanho das escamas.

Terpsichore senilis é uma espécie epífita, com ocorrência esporádica nas montanhas da região Sudeste do Brasil, tendo sido registrada apenas para a região da Serra da Mantiqueira, no Estado de São Paulo. Ocorre também no extremo Norte do País, próximo à fronteira com a Venezuela, sempre associada às florestas de altitude.
11. Terpsichore steyermarkii Labiak, Brittonia 52(3): 254. 2000.

Tipo: VENEZUELA. Bolivar: Chimanta Massif, vicinity of camp 4, southwestern edge of Apacara-tepui, 1600-1800 m, 15/IV/1953., Steyermark 75012 (holótipo NY!; isótipo US!).

Fig. 23-25.

Plantas epífitas ou rupícolas. Caule vertical, subereto, dorsiventral, com escamas castanhas, brilhantes, lanceoladas, 0,3-0,4 cm compr., glabras, apenas com o ápice ciliado. Frondes $15-30 \mathrm{~cm}$ compr., arqueadas; pecíolo 5-8 cm compr. e ca. 0,1 cm diâm., castanho, com setas castanhas conspícuas $0,1-0,15 \mathrm{~cm}$ compr.; lâmina com crescimento determinado, $3-4 \mathrm{~cm}$ larg., papirácea, lanceolada, pectinada, diminuindo gradativamente para a base e para o ápice, terminando geralmente em um segmento apical flabeliforme, frequentemente com fungos negros claviformes; raque esclerificada ou levemente recoberta pelo tecido lâminar no terço superior; segmentos ca. 0,3 cm larg. e $2 \mathrm{~cm}$ compr., lineares, a base simétrica e o ápice obtuso a algumas vezes arredondado, segmento terminal geralmente flabeliforme; indumento formado apenas por setas castanhas simples, uniformes, ca. $0,1 \mathrm{~cm}$ compr., presentes na raque e, apenas abaxialmente, na costa e tecido laminar; sinus inconspícuo, menor que a largura dos segmentos; nervuras pinadas, 1-furcadas, terminando medianamente entre a costa e a margem da lâmina, visíveis na face abaxial e apenas levemente na adaxial; hidatódios conspícuos, com pontos esbranquicados, localizados no ápice das nervuras. Soros arredondados, surgindo no ápice das nervuras, ca. 5-6(7) pares por segmento; esporângios glabros.

Material examinado: BRASIL. Roraima: Igarapé Arapopó, fronteira Brasil-Guiana, IX/1927, Luetzelburg 18202 (parátipo R). GUIANA. Mt. Roraima Expedition, 10/XII/1884, Thurn 180 (K); Mt. Roraima, XII/1884, Thurn 379 (K).

Distribuição geográfica: Venezuela, Guiana, Brasil.

Terpsichore steyermarkii é uma espécie bastante semelhante a T. alsopteris (C.V. Morton) A.R. Sm., da qual pode ser distinguida por apresentar os segmentos bastante contíguos, com a margem não ou apenas levemente revoluta, o segmento terminal flabeliforme e o indumento da raque formado apenas por um tipo de setas castanhas simples, semelhantes às do tecido laminar. Em oposição, T. alsopteris apresenta os segmentos bastante espaçados entre si (ca. de duas vezes a largura dos segmentos), a margem dos segmentos fortemente revoluta e o ápice atenuado, 


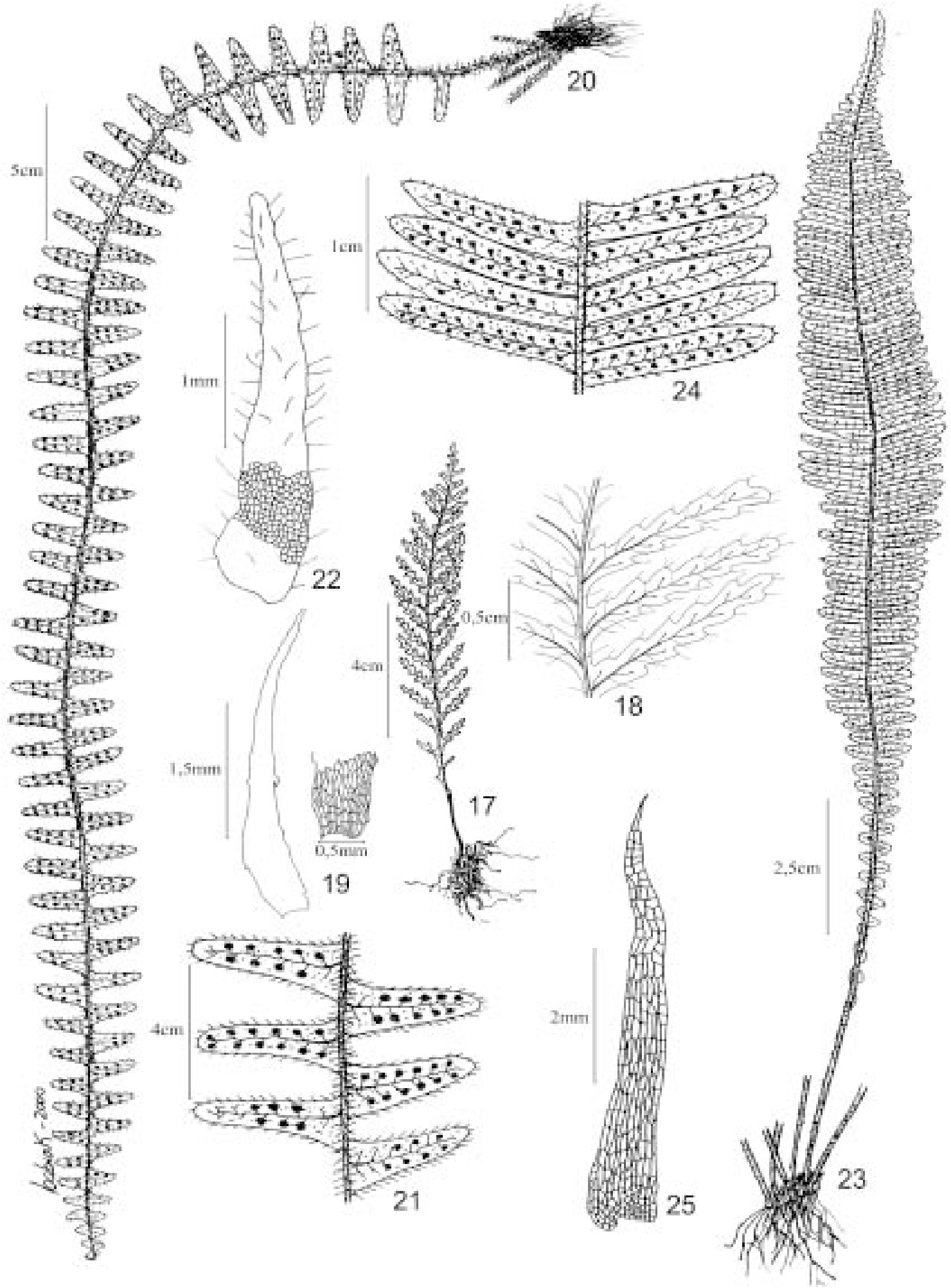

Figuras 17-25. 17-19. T. achilleifolia (Kaulf.) A.R. Sm. (Labiak 491). 17. Hábito. 18. Detalhe dos segmentos e nervuras. 19. Escama do caule e detalhe da escama do caule. 20-22. Terpsichore bradeana Labiak (Prance 10075). 20. Hábito. 21. Detalhe dos segmentos e nervuras. 22. Escama do caule. 23-25. T. steyermarkii Labiak (Steyermark 75012). 23. Hábito. 24. Detalhe dos segmentos e nervuras. 25. Escama do caule. 
pinatissecto, sem segmento terminal flabeliforme, além de o indumento da raque ser formado por dois tipos de setas, um maior, ca. 0,3 cm compr., e outro menor, ca. $0,1 \mathrm{~cm}$ compr., semelhante às setas da lamina foliar.

Terpsichore steyermarkii é também bastante semelhante a Terpsichore taxifolia (L.) A.R. Sm, da qual difere por apresentar setas na superfície abaxial da lâmina, lâmina linear-obovada, mais ampla no terço apical e reduzida na base, com cinco ou mais segmentos auriculiformes.

Terpsichore steyermarkii está restrita às regiões montanhosas entre a fronteira do Brasil e Venezuela, onde ocorre como epífita nas florestas de altitude.

12. Terpsichore taxifolia (L.) A.R. Sm., Novon 3(4): 488. 1993.

Polypodium taxifolium L., Sp. pl. 2: 1086. 1753. Ctenopteris taxifolia (L.) Copel., Philip. J. Sci. 84: 447. 1955 (1956). Grammitis taxifolia (L.) Proctor, Rhodora 63: 35. 1961. Lectótipo (desigando por Morton, Contr. U.S. Natl. Herb. 38(3): 109. 1967): Plumier, Tr. Foug. t. 89, baseado em material de Morne de la Calebasse, Martinica.

Polypodium L’herminieri Fée, Mém. Fam. Foug. 5: 238. 1852. Tipo: GUADELOUPE (holótipo provavelmente em $\mathrm{P}$ ), ex descr.

Polypodium L'herminieri Fée var. costaricense Rosenst., Repert. Spec. Nov. Regni Veg. 22: 17. 1925. Tipo: COSTA RICA. La Palma, 1.400 m, 14/III/1910, Brade 261 (holótipo B), ex descr.

Polypodium paulistanum Brade \& Rosenst., Arch. Inst. Biol. Veg. Rio de Janeiro 2: 3, t. 4. 1935. Terpsichore paulistana (Brade \& Rosenst.) A.R. Sm., Novon 3(4): 488. 1993. Tipo: BRASIL. São Paulo. Estação Biológica do Alto da Serra, Rio Terrível, X/1925, Brade 8396 (holótipo RB!; isótipos BM!, HB!).

Fig. 31-32.

Plantas epífitas. Caule horizontal, curto-reptante, dorsiventral, com escamas castanho-escuras, opacas, deltóide-lineares, 3-4 cm compr., glabras com apenas uma seta apical conspícua. Frondes $15-50 \mathrm{~cm}$ compr., arqueadas; pecíolo 1,5-8 cm compr. e ca. $0,1 \mathrm{~cm}$ diâm., castanho, cilíndrico, com setas castanhas conspícuas ca. 1-1,5 cm compr.; lâmina com crescimento determinado, 3-5 cm larg., papiráceae, lanceolada a linear-lanceolada, pinatissecta, diminuindo gradativamente para o ápice e mais abruptamente para a base, com fungos claviformes escuros presentes na face abaxial; raque esclerificada, variando de estraminea a castanha; segmentos 1,3-2,5 cm compr. e 0,2-0,3 cm larg., lineares, base simétrica e ápice obtuso a algumas vezes arredondado, perpendiculares a raque, segmento terminal pinatissecto, não flabeliforme; indumento ca. $0,1 \mathrm{~cm}$ compr., formado por setas castanhas simples, presentes na raque, margem dos segmentos e no tecido laminar adjacente aos soros; sinus mais estreito que a largura dos segmentos; nervuras pinadas, 1-furcadas, 7-13 pares por segmento, terminando medianamente entre a costa e a margem do segmento, visíveis em ambas a faces; hidatódios conspícuos, sem pontos esbranquiçados. Soros arredondados, surgindo no ápice das nervuras; esporângios glabros.

Material examinado: BRASIL. São Paulo: Estação Biológica, Alto da Serra, 234' 'S, 46 ${ }^{\circ} 16 \mathrm{~W}, 800-900$ m, 19/II/1929, Smith 1957 (GH, NY); Salesópolis, Estação Biológica de Boracéia, 900 m, 14/II/1999, Labiak 963 (SP).

Distribuição geográfica: Costa Rica, Panamá, Antilhas, Colômbia, Venezuela, Guiana, Suriname, Equador, Peru, Bolívia, Brasil.

Terpsichore taxifolia caracteriza-se por apresentar as escamas marginalmente glabras, com apenas um cílio apical, os segmentos contíguos entre si, lineares e levemente oblíquos à raque. Difere de T. alsopteris e T. steyermarkii, duas das espécies mais semelhantes, por apresentar o tecido laminar abaxialmente glabro, com apenas umas poucas setas presentes ao redor dos esporângios.

No Brasil existem apenas umas poucas coletas para o Estado de São Paulo, o que sugere uma ocorrência bastante restrita de Terpsichore taxifolia na região Sudeste do Brasil.

Zygophlebia L.E. Bishop, Amer. Fern J. 79: 107. 1989. Tipo: Polypodium sectifrons Kunze ex Mett. (=Zygophlebia sectifrons (Kunze ex Mett.) L.E. Bishop).

Plantas epífitas. Caule curto-reptante, dorsi-ventral, com escamas monocromáticas, ciliadas ou glandularpapilosas nas margens, brilhantes, filopódios presentes. Frondes monomorfas, cespitosas; pecíolo geralmente igual ou mais comprido que a lâmina, raras vezes menor; lâmina pinatissecta, com ou sem setas, tricomas glandulares simples ou bifurcados; nervuras pinadas, 1-2(3)-furcadas, geralmente unindo-se no ápice formando aréolas, algumas vezes livres; hidatódios ausentes. Soros separados, arredondados; paráfises presentes, constituídas por um pedicelo 1-seriado com 2-3 glândulas castanhas no ápice; esporângios glabros.

$\mathrm{O}$ gênero Zygophlebia caracteriza-se principalmente pela presença de filopódios, nervuras 


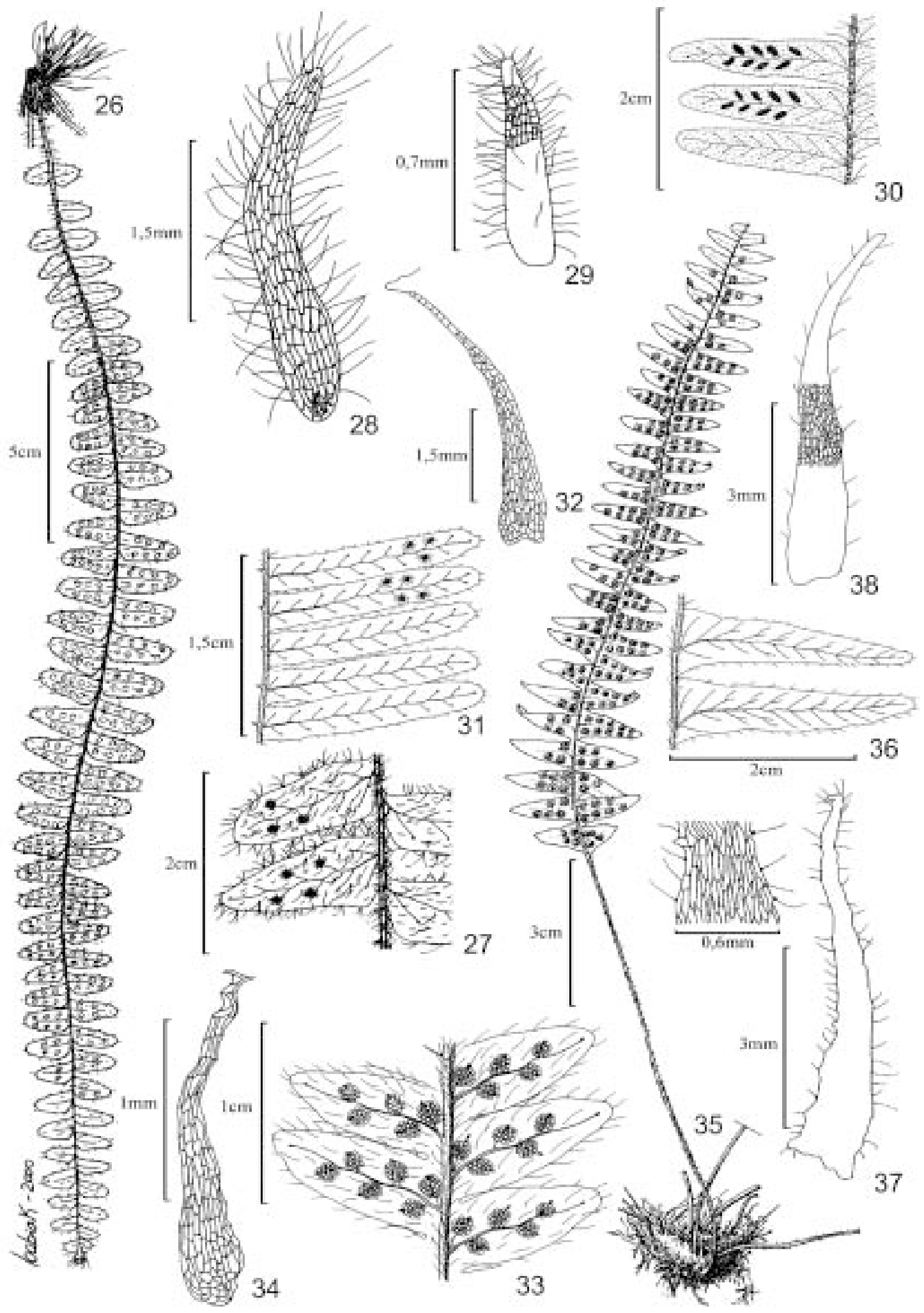

Figuras 26-38. 26-28. Terpsichore reclinata (Brack.) Labiak (Labiak 964). 26. Hábito. 27. Detalhe dos segmentos e nervuras. 28. Escama do caule. 29. T. cultrata (Bory ex Willd.) A.R. Sm. (Rodrigues 9877). Escama do caule. 30. T. lanigera (Desv.) A.R. Sm. (Luetzelburg 21609). Detalhe dos segmentos e nervuras. 31-32. T. taxifolia (L.) A.R. Sm. (Labiak 963). 31. Detalhe dos segmentos e nervuras. 32. Escama do caule. 33-34. T. gradata (Baker) A.R. Sm. (Labiak 486). 33. Detalhe dos segmentos e soros. 34 . Escama do caule. 35-37. T. chrysleri (Copel.) A.R. Sm. (Labiak 982). 35. Hábito. 36. Detalhe dos segmentos e nervuras. 37. Escama do caule e detalhe da escama do caule. 38. T. semihirsuta (Klotzsch) A.R. Sm. (Brade 9644). Escama do caule. 
regularmente areoladas (ao menos parcialmente), e pela ausência de hidatódios na lâmina. Uma característica também marcante é a posição das frondes em relação ao forófito, geralmente perpendiculares e geniculadas no ápice, dando à planta uma conformação pêndula (Bishop 1989; Smith \& Moran 1995).

A tendência em apresentar as nervuras areoladas é bastante incomum em Grammitidaceae e, ao menos no Novo Mundo, Zygophlebia é o único gênero com espécies pinadas ou pectinado-pinatífidas onde esta característica se apresenta de forma conspícua. Essas aréolas são formadas principalmente pela "união" de uma vênula fértil prolongada com a outra vênula, estéril, originada a partir da mesma nervura. Mais raramente a formação dessas aréolas se dá pela fusão de uma vênula estéril com outra vênula estéril situada em posição distal, ficando a vênula fértil situada no interior da aréola (Bishop 1989).

Excepcionalmente algumas espécies de Zygophlebia apresentam nervuras irregularmente anastomosadas, fato que está fortemente relacionado ao tamanho reduzido das frondes. Para Bishop (1989), este padrão sugere a origem desses grupos a partir de um ancestral de tamanho maior, com provável venação areolada.

Deve-se ressaltar que o gênero Ceradenia subgênero Filicipecten apresenta algumas espécies com nervuras irregularmente areoladas, sendo esse o grupo com características morfológicas mais semelhantes ao gênero Zygophlebia. No entanto, Ceradenia apresenta como característica bastante peculiar a presença de paráfises glandulares cerosas, enquanto que em Zygophlebia essas não apresentam funcionalidade glandular, apesar de morfologicamente semelhantes (Fig. 42) (Bishop 1989).

Ainda, diferenças siginificativas entre os dois gêneros podem ser encontradas na anatomia dos caules. Em ambos os gêneros o estelo é sifonostélico, porém, em Zygophlebia existem perfurações ventrolaterais não associadas com os traços foliares, característica que não está presente em nenhuma das espécies de Ceradenia já analisadas quanto a esse caracter.

Os esporos em Zygophlebia não diferem significativamente dos das outras espécies de Grammitidaceae. Esses são geralmente clorofilados, triletes, tetraédricos, variando de 20 a $60 \mu \mathrm{m}$ de diâmetro (Fig. 43-44).

$\mathrm{O}$ número cromossômico é ainda desconhecido para o gênero.

Zygophlebia é um gênero essencialmente
Neotropical, com cerca de 10 espécies, ocorrendo como epífitas nas florestas de altitude principalmente da América Central e Norte da América do Sul. Ocorre também na África e Madagascar, estando ali representada apenas por Zygophlebia villosissima (Hook.) L.E. Bishop (vide Bishop 1989).

No Brasil apenas uma única espécie foi registrada, a saber:

13. Zygophlebia longipilosa (C. Chr.) L.E. Bishop, Amer. Fern J. 79(3): 109. 1989.

Polypodium longipilosum C. Chr., Bot. Tidsskr. 25: 78. 1903. Polypodium villosum Fée, Cryp. vasc. Br. 2: 54, t. 95, f. 3. 1873 non illeg., non Linnaeus (1753) nec Karsten (1865-69). Tipo: BRASIL. Rio de Janeiro. "Source do Rio Soberbo en haut des Orgues", Glaziou 4411 (holótipo P).

Ctenopteris subcrassa Copel., Philipp. J. Sci. 84: 468. 1955 (1956). Grammitis subcrassa (Copel.) C.V. Morton, Contr. U.S. Natl. Herb. 38: 234. 1973. Tipo: BRASIL. São Paulo. Serra do Mar, Campo Grande, 800 m, 16/III/1913, Brade 5833 (holótipo US!, isótipos HB!, SP!).

Fig. 39-44.

Plantas epífitas. Caule horizontal, curto-reptante, revestido de escamas castanhas, brilhantes, 0,5-0,7 mm compr., deltóide-lineares, glabras. Frondes 10-40 cm compr. e 2-5 cm larg., cespitosas, eretas a levemente prostradas; pecíolo $3-7 \mathrm{~cm}$ compr., castanho-escuro, com setas castanhas ca. $0,2 \mathrm{~cm}$ compr. Lâmina pinatífita a pinatissecta, linear-elíptica a lanceolada, cartácea; segmentos 0,5-1,5 cm compr. e ca. 0,3 cm larg., deltóides a deltóide-lineares, simétricos, levemente oblíquos à raque, com ápice obtuso e a margem levemente cartilaginosa; indumento constituido de setas castanhas sobre a raque, nervuras e margem dos segmentos, principalmente na face abaxial, raramente presentes sobre o tecido laminar (ou apenas nas proximidades dos soros); raque imersa no tecido laminar; sinus menor que largura dos segmentos. Nervuras pinadas, 1 -furcadas, terminando próximo à margem do segmento. Soros arredondados, terminais sobre os ramos acroscópicos, com paráfises castanhas semelhantes às setas da lâmina.

Material examinado: BRASIL. Rio de Janeiro: Terezópolis, Serra do Cavalo, XI/1929, Brade 9992 (NY); Serra dos Órgãos, Pedra do Frade, 1.600 m, 10/VIII/1940, Brade 16673 (RB); Frade de Macahé, 17-21/VI/1937, Brade 15806 (RB, BM). São Paulo: 
Paranapiacaba (via férrea São Paulo-Santos), Estação Biológica, 28/IX/1967, Handro 1205 (SPF); Campos do Jordão, estrada para Pindamonhangaba, $1.900 \mathrm{~m}$, 28/VI/1998, Labiak 662 (SP). Paraná: Piraquara,

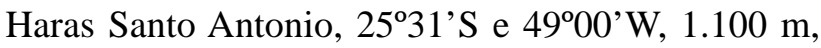
17/II/2004, Kersten 801 (UPCB, MBM). Santa Catarina: Cambajuva, São Joaquim, $1.200 \mathrm{~m}$, 23-29/I/1950, Reitz 3473B (RB, US). Rio Grande do Sul: São Francisco de Paula, Taimbé, $700 \mathrm{~m}$, 31/XII/1961, Sehnem 7964 (PACA).
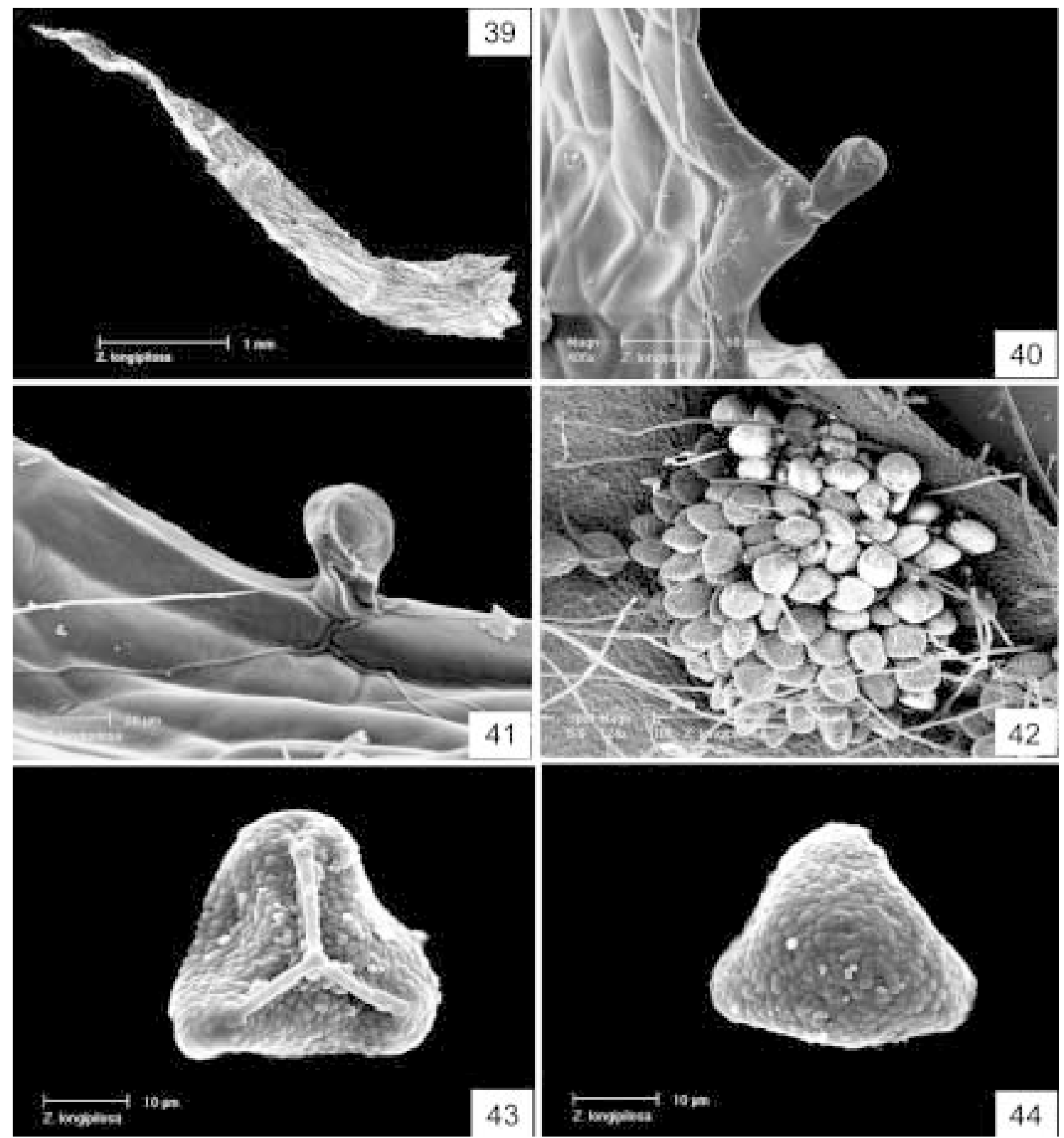

Figuras 39-44. Zygophlebia longipilosa (C. Chr. ) L.E. Bishop (Labiak 662). 39. Escama do caule. 40. Detalhe da escama do caule. 41. Detalhe da escama do caule. 42. Soro com esporângios glabros e paráfises setosas. 43. Esporo em vista proximal. 44. Esporo em vista distal. 
Apesar de ocorrer desde o Estado do Rio de Janeiro até Santa Catarina, parece ser uma espécie bastante rara, haja vista o escasso número de materiais disponíveis nos herbários. Ocorre geralmente como planta epífita, no interior das áreas primárias de Floresta Atlântica.

\section{Agradecimentos}

$\mathrm{O}$ primeiro autor agradece ao $\mathrm{CNPq}$ (Conselho Nacional de Desenvolvimento Científico e Tecnológico) pela Bolsa de Doutorado e auxílio financeiro para realização das atividades de pesquisa no Brasil; à "Andrew W. Mellon Foundation", por financiar a visita aos Herbários de Nova Iorque (NY), Cambridge (GH) e Washington (US); e à Fundação Botânica Margaret Mee, que financiou a visita aos Herbários de Bruxelas (BR), Kew (K) e Londres (BM); ao Instituto de Botânica e à Universidade de São Paulo, por ceder em seus espaços físicos e infra-estrutura; aos Curadores dos herbários pelos empréstimos dos materiais; ao Robbin C. Moran, pela acolhida no Jardim Botânico de Nova Iorque; à Diana Carneiro, que gentilmente ilustrou algumas das espécies para este trabalho.

\section{Referências bibliográficas}

Bishop, L.E. 1974. Revision of the genus Adenophorus (Grammitidaceae). Brittonia 26(3): 217-240.

Bishop, L.E. 1977. The American species of Grammitis sect. Grammitis. American Fern Journal 67(4): 101-106.

Bishop, L.E. 1978. A revision of the genus Cochlidium (Grammitidaceae). American Fern Journal 68(3): 76-94.

Bishop, L.E. 1988. Ceradenia, a new genus of Grammitidaceae. American Fern Journal 78(1): 1-5.

Bishop, L.E. 1989. Zygophlebia, a new genus of Grammitidaceae. American Fern Journal 79(3): 103-118.

Bishop, L.E. \& Smith, A.R. 1992. Revision of the fern genus Enterosora (Grammitidaceae) in the New World. Systematic Botany 17(3): 345-362.

Bishop, L.E. \& Smith, A.R. 1995. Grammitidaceae. Pp. 135-158. In: J.A. Steyermark, P.E. Berry \& B.K. Holst (eds.). Flora of the Venezuelan Guayana 2: Pteridophytes, Spermatophytes (Acanthaceae-Araceae). Portland, Missouri Botanical Garden, Timber Press.

Copeland, E.B. 1956. Ctenopteris in America. Philippine Journal of Science 84: 381-471.

Davidse, G.M., Sousa S. \& Knapp, S. 1995. Flora Mesoamericana. v.1. Ciudad de México, Universidad Nacional Autónoma de México. de la Sota, E.R.; Cassá, L.A.P. \& Ponce, M.M. 2000. Grammitidaceae (Pteridophyta) de Argentina y Chile. Darwiniana 38(3-4): 299-306.

Font Quer, P. 1989. Diccionario de Botánica. Santo Andreu de la Barca, Editorial Labor.

Foster, R.C. 1949. Practical plant anatomy. Ed. 2. New York, D. Van Nostrand Co.

Labiak, P.H. 2000. New species and new combinations in neotropical Grammitidaceae (Pteridophyta). Brittonia 52(3): 246-255.

Labiak, P.H. 2003. A new combination in the fern genus Ceradenia (Grammitidaceae). Kew Bulletin 58(4): 991-994.

Labiak, P.H. \& Prado, J. 2003. Grammitidaceae (Pteridophyta) no Brasil, com ênfase nos gêneros Ceradenia, Cochlidium e Grammitis. Hoehnea 30(3): 243-283.

Labiak, P.H. \& Prado, J. 2005a. As espécies de Lellingeria A.R. Sm. \& R.C. Moron (Grammitidaceae Pteridophyta) do Brasil. Revista Brasileira de Botânica 28(1): 1-22.

Labiak, P.H. \& Prado, J. 2005b. As espécies de Melpomene e Micropolypodium (Grammitidaceae - Pteridophyta) no Brasil. Boletim de Botânica da Universidade de São Paulo 23(1): 51-69.

Mickel, J.T. 1973. Fungi on Ferns. New and Views 9: 4.

Pichi-Sermolli, R.E.G. 1996. Authors of scientific names in Pteridophyta. Kew, Royal Botanical Gardens.

Proctor, G.R. 1985. Ferns of Jamaica. London, British Museum (Natural History).

Rizzini, C.T. \& Rizzini, C.M. 1983. Dicionário Botânico Clássico Latino-português Abonado. Rio de Janeiro, IBDF.

Smith, A.R. 1992. A review of the genus Micropolypodium (Grammitidaceae). Novon 2(4): 419-425.

Smith, A.R. 1993. Terpsichore, a new genus of Grammitidaceae (Pteridophyta). Novon 3(4): 478-489.

Smith, A.R. 1995. New combinations in Neotropical Grammitidaceae (Pteridophyta). Novon 5(1): 21-22.

Smith, A.R. \& Moran, R.C. 1995. Terpsichore e Zygophlebia. In Psilotaceae a Salviniaceae (R. Riba \& R.C. Moran, eds.). v.1. Pp.385-393. In Flora Mesoamericana (G.M. Davidse; S. Sousa \& S. Knapp, eds.). Ciudad de México, Universidad Nacional Autónoma de México.

Stearn, W.T. 1995. Botanical Latin. $4^{\mathrm{a}}$ ed. Portland, Timber Press.

Wagner, F.S. 1985. Bilateral spores in new world grammitid ferns. American Fern Journal 75(1): 6-11.

Walker, T.G. 1966. A cytotaxonomic survey of the pteridophytes of Jamaica. Transactions of the Royal Society of Edinburgh 66(9): 169-237.

Walker, T.G. 1985. Cytotaxonomic studies of the ferns of Trinidad 2: the citology and taxonomic implications. Bulletin British Museum (Natural History), Botany 13(2): 149-249. 
